\title{
Arachidonic acid and cancer risk: a systematic review of observational studies
}

\author{
Mai Sakai ${ }^{1,2^{*}+}$, Saki Kakutani ${ }^{1,3 \dagger}$, Chika Horikawa ${ }^{3}$, Hisanori Tokuda ${ }^{3}$, Hiroshi Kawashima ${ }^{3}$, Hiroshi Shibata ${ }^{2,3}$, \\ Hitomi Okubo ${ }^{1}$ and Satoshi Sasaki ${ }^{1}$
}

\begin{abstract}
Background: An n-6 essential fatty acid, arachidonic acid (ARA) is converted into prostaglandin $E_{2}$, which is involved in tumour extension. However, it is unclear whether dietary ARA intake leads to cancer in humans. We thus systematically evaluated available observational studies on the relationship between ARA exposure and the risk of colorectal, skin, breast, prostate, lung, and stomach cancers.

Methods: We searched the PubMed database for articles published up to May 17, 2010. 126 potentially relevant articles from the initial search and 49,670 bibliographies were scrutinised to identify eligible publications by using predefined inclusion criteria. A comprehensive literature search yielded 52 eligible articles, and their reporting quality and methodological quality was assessed. Information on the strength of the association between ARA exposure and cancer risk, the dose-response relationship, and methodological limitations was collected and evaluated with respect to consistency and study design.
\end{abstract}

Results: For colorectal, skin, breast, and prostate cancer, 17, 3, 18, and 16 studies, respectively, were identified. We could not obtain eligible reports for lung and stomach cancer. Studies used cohort $(n=4)$, nested case-control $(n=12)$, case-control $(n=26)$, and cross-sectional $(n=12)$ designs. The number of subjects $(n=15-88,795)$, ARA exposure assessment method (dietary intake or biomarker), cancer diagnosis and patient recruitment procedure (histological diagnosis, cancer registries, or self-reported information) varied among studies. The relationship between ARA exposure and colorectal cancer was inconsistent based on ARA exposure assessment methodology (dietary intake or biomarker). Conversely, there was no strong positive association or dose-response relationship for breast or prostate cancer. There were limited numbers of studies on skin cancer to draw any conclusions from the results.

Conclusions: The available epidemiologic evidence is weak because of the limited number of studies and their methodological limitations, but nonetheless, the results suggest that ARA exposure is not associated with increased breast and prostate cancer risk. Further evidence from well-designed observational studies is required to confirm or refute the association between ARA exposure and risk of cancer.

\section{Background}

Cancer remains an important health problem worldwide. It is estimated that 58.8 million people died of all causes in 2004 [1]. Deaths from cancer represented around one-eighth of these deaths, although many people who died had cancer even though it was not the direct cause of death. By 2030, it is projected that there will be

\footnotetext{
*Correspondence: Mai_Sakai@suntory.co.jp

${ }^{\dagger}$ Equal contributors

'Department of Social and Preventive Epidemiology, School of Public Health, The University of Tokyo, Tokyo, Japan

${ }^{2}$ Quality Assurance Department, Suntory Wellness Limited, Tokyo, Japan

Full list of author information is available at the end of the article
}

approximately 26 million new cancer cases and 17 million cancer deaths per year [2]. Given these considerations, the prevention of cancer is a major public health issue around the world.

It is well established that dietary and other lifestyle factors play an important role in cancer control. In terms of dietary factors, earlier studies suggested a relationship between fat intake and the risk of several types of cancer. Prospective cohort studies found no association between fat intake and breast cancer, but a randomised trial organised within the Women's Health Initiative trial suggested a $9 \%$ reduction of borderline significance in

\section{Biomed Central}


breast cancer occurrence with decreased fat intake [3-5]. Analysis of the information in the Multiethnic Cohort Study found that intake of different types of fat indicated no association with overall prostate cancer risk or with non-localised or high-grade prostate cancer [6]. A prospective cohort study and a clinical trial failed to find evidence for an association between fat intake and colorectal cancer $[7,8]$. A dietary intervention study demonstrated that a reduction in fat intake reduces the risk of skin cancer $[9,10]$, but the evidence from observational studies $[11,12]$ has been controversial. Japan is a high-risk area for stomach and lung cancer, but no association with fat intake and these types of cancer has been suggested [2].

Essential fatty acids, namely $n-3$ and $n-6$ fatty acids, are involved in many important biological functions [13-16]. They play a structural role in cell membranes, influencing their fluidity and membrane enzyme activities; in addition, some are the precursors of prostaglandins and other lipid mediators. Arachidonic acid (ARA) is an n-6 essential fatty acid and also a major constituent of biomembranes. It is released from membranes by phospholipase $\mathrm{A}_{2}$ and converted into various lipid mediators that exert many physiological actions [17-19]. Many studies have shown that lipid mediators derived from ARA, particularly prostaglandin $\mathrm{E}_{2}\left(\mathrm{PGE}_{2}\right)$, are associated with various diseases, which is mainly based on the fact that cyclooxygenase (COX) inhibitors are effective against those conditions [20-24]. $\mathrm{PGE}_{2}$ is regarded as enhancing tumour extension as well, but it has been suggested that some other ARA mediators inhibit tumour growth [21-25]. In animal models, ARA administration did not affect tumour extension [26,27]. Some observational studies also suggested no relationship between ARA exposure and cancer risk [28,29]. However, there are the inconsistent observational studies that ARA exposure was positively correlated with the risk of colorectal cancer [30,31]. ARA is one of the major polyunsaturated fatty acid, and this inconsistency is not negligible.

No systematic review or meta-analysis has been conducted to evaluate the long-term effects of ARA intake and blood or tissue ARA composition on the risk of colorectal, skin, breast, prostate, lung, and stomach cancers in free-living populations. The objective of this study was to systematically evaluate available observational studies on the relationship between ARA intake and blood or tissue composition of ARA and the risk of these types of cancer.

\section{Methods}

\section{Search strategy}

The PubMed database (http://www.ncbi.nlm.nih.gov/ pubmed/) was searched for observational studies on the relationship between dietary or blood ARA levels with cancer risk that were published up to May 17, 2010. To identify target articles effectively, the strategy for the PubMed search was as follows: keywords for outcome and study types were adopted as commonly used terms representing cancer and study design, whereas terms for exposure were selected from specific words that stand for "arachidonic acid" (see Additional file 1). The initial PubMed search yielded 126 potentially relevant articles.

\section{Study selection}

Inclusion criteria were English articles that reported original data on the relationship between ARA exposure (intake or blood level) and target cancer risk in freeliving adults. Eligible study designs were cohort, casecontrol, or cross-sectional studies, and target types of cancer were colorectal, skin, breast, prostate, lung, or stomach cancer. Also included were studies investigating tissue ARA levels and target cancer risk. The study selection process is presented in Figure 1. We omitted reports in which titles or abstracts indicated that: (1) they were not human studies; (2) they were limited to special populations such as people with unusual eating habits; (3) they were intervention studies; or (4) they were not about the target cancers and fatty acids (not fat). We then evaluated the full text of the passed articles. Titles and abstracts of 126 identified publications from the PubMed database were checked and reviewed against the predefined inclusion criteria, and afterward, the full text of 52 articles were similarly assessed for eligibility by three authors (SK, CH, and HT, not independently). The 49,670 bibliographies of these full-text articles were scrutinised to identify additional eligible publications. One article on breast cancer was excluded because an inaccuracy of ARA assessment was clearly reported, although this article met the inclusion criteria described above [32]. Finally, 52 eligible articles were included in this review: 21 and 31 articles were obtained from primary PubMed searches and bibliographies, respectively.

\section{Quality assessment and data extraction}

Quality assessment was conducted based on the reporting quality and methodological quality of each study. The reporting quality shows whether the necessary information for observational studies is well indicated. It is the number of fulfilled items from the Strengthening the Reporting of Observational Studies in Epidemiology Statement (STROBE) checklist and varied 0 to 34 [33]. The reporting quality of included observational studies was assessed individually by two reviewers ( $\mathrm{CH}$ and $\mathrm{HT}$ ) and then confirmed by another two authors (SK and MS). The methodological quality, a level of suitability of methods used in a study, was assessed by two authors (SK and MS) qualitatively from the following methodological aspects used in the article: subject selection, ARA exposure assessment, diagnosis or recruitment 


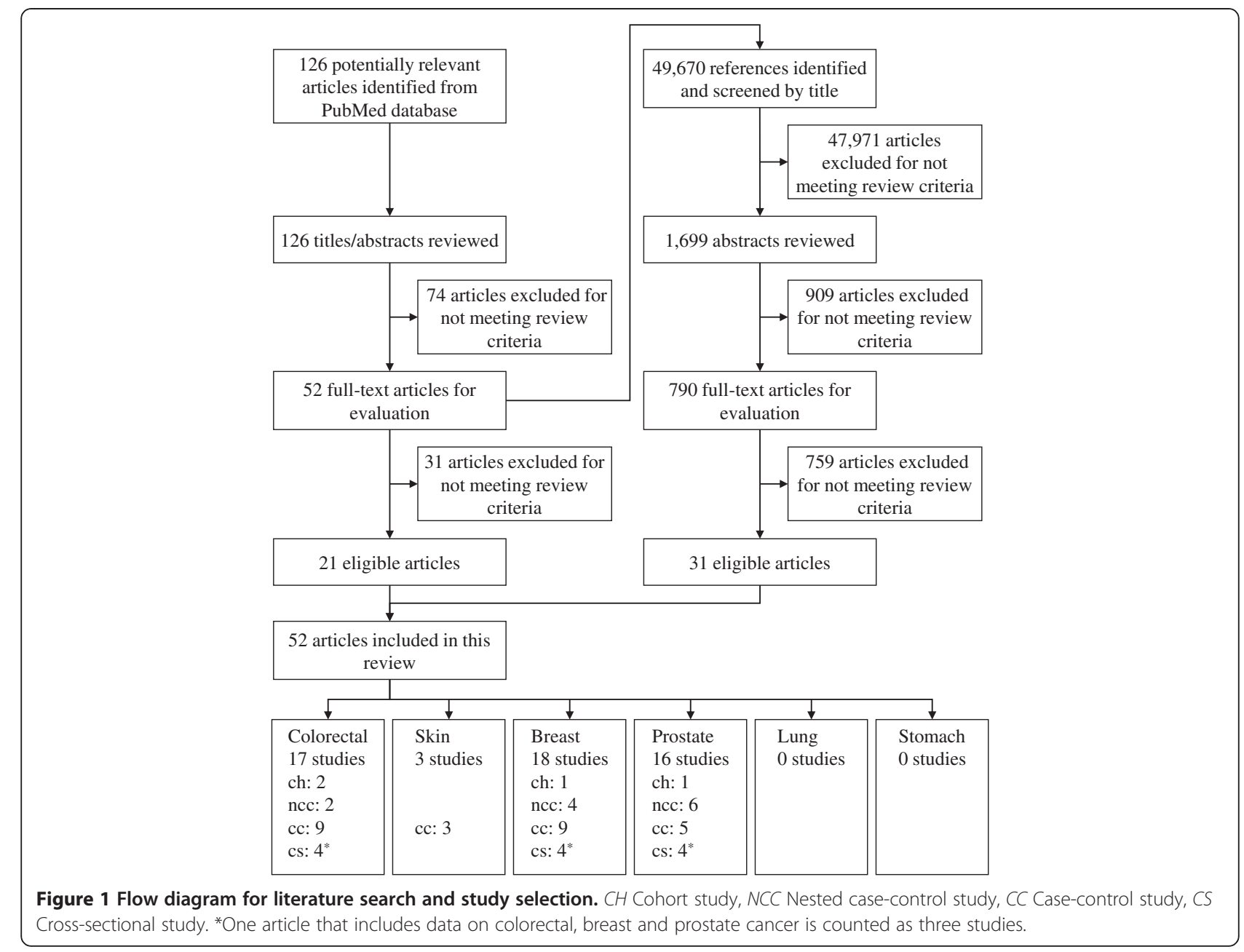

procedure of cancer patients, methods for controlling confounders, and statistical analysis.

For each eligible article, the following information was tabulated: authors and year of publication, study settings and design, subject characteristics (such as age, sex, and number), matching strategy (if applicable), ARA exposure assessment used (as well as information about validity or precision), outcome assessment, adjusted confounders, reporting quality score from the STROBE checklist, and main findings from the fully adjusted model. Case-control studies were classified into two groups based on whether they reported temporal study settings information between exposure and outcome assessment: "case-control study (temporal relationship among exposure and outcome is demonstrated)" was defined as articles in which ARA exposure preceded the occurrence of cancer, whereas "case-control study (temporal relationship among exposure and outcome is unclear)" did not describe sufficient temporal information about exposure and outcome assessment.

Our qualitative definition of the study quality was as below: the reporting quality score under 13 or the insufficient temporal information, low; the other studies were qualitatively divided into high/medium/low according to their strength and weakness. A meta-analysis was not conducted because of the heterogeneity among studies, particularly subject characteristics and exposure/outcome assessment, and the insufficient number of studies with high methodological quality suitable for a metaanalysis. Therefore, qualitative assessment of ARA intake and cancer risk is presented in this review.

\section{Results}

For colorectal, skin, breast, and prostate cancer, 52 eligible articles were selected from potentially related reports and were included in the present systematic review (Figure 1); the number of each was 17, 3, 18, and 16 studies, respectively. In contrast, we could not identify eligible reports for lung and stomach cancer.

\section{Colorectal cancer}

Major characteristics are shown in Table 1 [28,30,31,34-47]. Five reports did not provide sufficient information about the methodology of outcome measurement. Some cohort 
Table 1 Summary of observational studies on the association between ARA and risk of colorectal cancer

\begin{tabular}{|c|c|c|c|c|c|c|c|c|}
\hline \multirow[t]{2}{*}{ References } & \multirow[t]{2}{*}{ Study } & \multirow[t]{2}{*}{ Subjects } & \multirow{2}{*}{$\begin{array}{l}\text { Exposure } \\
\text { Assessment }\end{array}$} & \multirow{2}{*}{$\begin{array}{l}\text { Colorectal cancer } \\
\text { assessment } \\
\text { (diagnosis) }\end{array}$} & \multirow{2}{*}{$\begin{array}{l}\text { Adjustment for potential } \\
\text { confounders }\end{array}$} & \multirow{2}{*}{$\begin{array}{l}\text { Assessment } \\
\text { of reporting } \\
\text { quality * }\end{array}$} & \multicolumn{2}{|l|}{ Main findings } \\
\hline & & & & & & & Intergroup comparison & $\begin{array}{l}\mathrm{P} \text { or } \\
\text { Ptrend }\end{array}$ \\
\hline
\end{tabular}

\section{Study design: cohort study}

Exposure assessment: dietary intake

\begin{tabular}{|c|c|c|}
\hline $\begin{array}{l}\text { Murff et al. } \\
2009 \text { [30] }\end{array}$ & $\begin{array}{l}\text { SWHS, China, 1996- } \\
\text { 2007, prospective } \\
\text { cohort design (7-year } \\
\text { biennial follow-up, } \\
\text { follow-up rate }=96.7 \% \text { ) }\end{array}$ & $\begin{array}{l}73,243 \text { women aged } 40- \\
70, \text { no prior history of } \\
\text { cancer }\end{array}$ \\
\hline $\begin{array}{l}\text { Lin et al. } 2004 \\
\text { [28] }\end{array}$ & $\begin{array}{l}\text { WHS, USA, 1993-2003, } \\
\text { prospective cohort } \\
\text { design nested } \\
\text { randomized, double- } \\
\text { blind, placebo- } \\
\text { controlled } 2 \times 2 \\
\text { factorial aspirin and } \\
\text { vitamin A trial (average } \\
8.7 \text { years follow-up) }\end{array}$ & $\begin{array}{l}37,547 \text { female health } \\
\text { professionals aged } \geq 45, \\
\text { free of heart disease and } \\
\text { cancer except NMSC }\end{array}$ \\
\hline
\end{tabular}

$\begin{array}{lll}\text { SWHS's FFQ, } & \text { Self-reported } & \text { Age at baseline, total } \\ 77 \text { items, } & \text { physician diagnosis, } & \text { energy intake, smoking } \\ \text { previously } & \text { combined with } & \text { status, alcohol intake, } \\ \text { validated } & \text { annual record } & \text { physical activity, energy- } \\ \text { against 24x } & \text { linkage with the } & \text { adjusted total red meat } \\ 24-H D R & \text { Shanghai Cancer } & \text { consumption, menopausal } \\ & \text { Registry and } & \text { status, use of HRT, } \\ & \text { Shanghai Vital } & \text { multivitamin, aspirin, total } \\ & \text { Statistics database } & \text { n-3 PUFA intake, n-6 to n-3 } \\ & & \text { PUFA ratio }\end{array}$

\section{FFQ, $131 \quad$ Self-reported}

validated against $2 \times 7$ day WR

\section{physician diagnosi} reviewed and

Age, treatment assignment, BMI, family history of CRC, colorectal polyps, physical activity, smoking status, total energy intake

\section{Study design: nested case-control study}

\section{Exposure assessment: blood ARA leve}

$\begin{array}{lllll}\text { Hall et al. } & \text { PHS, USA, 1982-1995, } & \text { 178 CRC patients, 282 } & \text { Whole blood } & \text { Self-report, } \\ 2007 \text { [34] } & \text { nested case-control } & \text { controls, male physicians } & \text { fatty acids, GC } & \text { combined with } \\ & \text { design within a } & \text { without history of cancer } & \text { analysis } & \text { review of medical } \\ & \text { randomized, double- } & \text { aged 40-84 years at } & \text { blinded to } & \text { records } \\ \text { blind, placebo-controlled } & \text { baseline, } 1 \text { case matched } & \text { case-control } & \\ & \text { factorial aspirin and beta- } & \text { with 1-2 controls by age, } & \text { status at a } & \\ \text { carotene trial (average 5 } & \text { smoking status } & \text { time, precision } & \\ \text { and 7 years follow-up) } & & \text { indicated }\end{array}$

None
18 Dietary ARA
intake, $\mathrm{g} / \mathrm{da}$,

quintile,

median

Q1: 0.02

Q2: 0.03

Q3: 0.05

Q4: 0.06

Q5: 0.09

Dietary ARA

intake, \%

energy,

quintile,

median

$\begin{array}{lll}\text { Q1: } 0.04 & 1.00 & 0.55 \\ \text { Q2: } 0.06 & 0.86(0.57-1.32) & \\ \text { Q3: } 0.07 & 0.84(0.55-1.28) \\ \text { Q4: } 0.09 & 0.73(0.47-1.14) \\ \text { Q5: } 0.12 & 0.90(0.59-1.36)\end{array}$

$\begin{array}{lll}\text { ARA } & \text { ARA } & \text { P } \\ \text { composition\%, } & \text { composition\%, } & \\ \text { geometric } & \text { geometric } & \\ \text { mean(95\%Cl) } & \text { mean(95\%Cl) } \\ \text { Case: } & \text { Control: } & \\ \text { 9.77(9.57-9.99) } & \text { 9.93(9.77-10.10) } & \text { Not }\end{array}$

significant 
Table 1 Summary of observational studies on the association between ARA and risk of colorectal cancer (Continued)

\begin{tabular}{|c|c|c|c|c|c|}
\hline $\begin{array}{l}\text { Kojima et al. } \\
2005 \text { [35] }\end{array}$ & $\begin{array}{l}\text { JACC Study, Japan, } \\
\text { 1988-1997, nested case- } \\
\text { control design (7 years } \\
\text { follow-up) }\end{array}$ & $\begin{array}{l}169 \text { primary CRC patients, } \\
481 \text { controls without } \\
\text { previous history of cancer, } \\
\text { aged } 40-79 \text { years at } \\
\text { baseline, } 1 \text { case matched } \\
\text { with } 2-3 \text { controls by age, } \\
\text { sex, resident area }\end{array}$ & $\begin{array}{l}\text { Serum fatty } \\
\text { acids, GC } \\
\text { analysis } \\
\text { blinded to } \\
\text { case-control } \\
\text { status, } \\
\text { precision not } \\
\text { indicated }\end{array}$ & $\begin{array}{l}\text { Population-based } \\
\text { cancer registries, } \\
\text { supplemented by } \\
\text { death certificates }\end{array}$ & $\begin{array}{l}\text { Age at completing final } \\
\text { education, family history of } \\
\text { CRC, BMI, smoking status, } \\
\text { alcohol intake, intake of } \\
\text { green leafy vegetables, } \\
\text { physical activity }\end{array}$ \\
\hline
\end{tabular}

\section{Study design: case-control study (temporal relationship among exposure and outcome is demonstrated)}

\section{Exposure assessment: dietary intak}

Theodoratou Survey, UK, 1999-2006,

et al. 2007 case-control design

[36]

Nkondjock

et al. 2003

Survey, Canada, 1989-

1993, case-control

design
1,455 primary CRC patients Scotish FFQ, aged 16-79, 1,455 controls 150 items,

shown), matched by age, sex, resident area 50 items, against 4-day WR, (response rate $=$ case $82 \%$, control

97\%)

402 CRC patients aged 35- FFQ, 132 79, 688 controls, matched items

by age, language, place of validated residence
Not shown

Histological diagnosis
Family history of CRC, tota energy intake, total fiber intake, alcohol intake, NSAIDs use, smoking status, BMI, physical activity, total fatty acid intake

Age, BMl, family history of CRC, marital status, physica activity

\section{ARA}

composition

weight $\%$ of

total serum

lipids, quartile

$\begin{array}{lll}\text { Men: } & \text { Men: } & \text { Men: } \\ \text { Q1: }<3.71 & 1.00 & 0.99\end{array}$

Q2: $3.71-4.619 \quad 1.24(0.55-2.78)$

Q3: 4.62-5.269 $0.79(0.32-1.96)$

Q4: $\geq 5.27 \quad 1.16(0.49-2.75)$

Women: Women: Women:

$\begin{array}{lll}\text { Q1: }<4.20 & 1.00 \quad 0.40\end{array}$

Q2: 4.20-4.879 $0.67(0.31-1.46)$

Q3: 4.88-5.634 $0.49(0.22-1.10)$

Q4: $\geq 5.635 \quad 0.65(0.30-1.44)$

residence against 7-day

20

\begin{tabular}{|c|c|c|}
\hline $\begin{array}{l}\text { Dietary ARA } \\
\text { intake, mg/ } \\
\text { day, quartile }\end{array}$ & OR (95\%Cl) & Ptrend \\
\hline Q1: 0-5.82 & 1.00 & 0.163 \\
\hline Q2: $5.83-8.40$ & $1.09(0.87-1.37)$ & \\
\hline Q3: 8.41-11.34 & $0.79(0.63-1.01)$ & \\
\hline Q4: $\geq 11.35$ & $0.93(0.72-1.19)$ & \\
\hline $\begin{array}{l}\text { Dietary ARA } \\
\text { intake, g/day, } \\
\text { quartile }\end{array}$ & OR $(95 \% \mathrm{Cl})$ & Ptrend \\
\hline Q1:<0.06 & 1.00 & 0.001 \\
\hline Q2:0.06-0.09 & $1.24(0.84-1.84)$ & \\
\hline Q3:0.10-0.14 & $1.64(1.12-2.40)$ & \\
\hline $24:>0.14$ & $2.11(1.47-3.06)$ & \\
\hline
\end{tabular}


Table 1 Summary of observational studies on the association between ARA and risk of colorectal cancer (Continued)

\begin{tabular}{|c|c|c|c|c|c|c|c|c|c|}
\hline \multirow[t]{13}{*}{$\begin{array}{l}\text { Slattery et al. } \\
1997 \text { [37] }\end{array}$} & \multirow[t]{13}{*}{ Survey, USA, 1991-1994 } & \multirow{13}{*}{$\begin{array}{l}1993 \text { CRC patients aged } \\
30-79,2410 \text { controls } \\
\text { without history of CRC } \\
\text { (population characteristic } \\
\text { partially not shown), } \\
\text { matched by age, sex, } \\
\text { resident state }\end{array}$} & \multirow{13}{*}{$\begin{array}{l}\text { CARDIA Diet } \\
\text { History } \\
\text { Questionnaire, } \\
\text { validated } \\
\text { against } 7 \times 24 \text { - } \\
\text { HDR }\end{array}$} & \multirow[t]{13}{*}{ Cancer registries } & \multirow{13}{*}{$\begin{array}{l}\text { Total energy intake, age at } \\
\text { selection, BMI, family } \\
\text { history of CRC, physical } \\
\text { activity, dietary cholesterol, } \\
\text { calcium, fiber, NSAIDs use }\end{array}$} & \multirow[t]{13}{*}{19} & $\begin{array}{l}\text { Dietary ARA } \\
\text { intake, g/MJ, } \\
\text { quintile }\end{array}$ & OR $(95 \% \mathrm{Cl})$ & Ptrend \\
\hline & & & & & & & Men: & Men: & Men: \\
\hline & & & & & & & Q1:<0.17 & 1.00 & Not shown \\
\hline & & & & & & & Q2:0.17-0.22 & $1.25(0.95-1.65)$ & \\
\hline & & & & & & & Q3:0.23-0.26 & $1.08(0.81-1.44)$ & \\
\hline & & & & & & & Q4:0.27-0.33 & $1.37(1.03-1.83)$ & \\
\hline & & & & & & & Q5:>0.33 & $1.17(0.85-1.61)$ & \\
\hline & & & & & & & Women: & Women: & Women: \\
\hline & & & & & & & Q1:<0.039 & 1.00 & Not shown \\
\hline & & & & & & & Q2:0.039-0.051 & $0.99(0.73-1.33)$ & \\
\hline & & & & & & & Q3:0.052-0.063 & $1.15(0.86-1.55)$ & \\
\hline & & & & & & & Q4:0.064-0.077 & $0.98(0.72-1.35)$ & \\
\hline & & & & & & & Q5: $>0.077$ & $0.98(0.70-1.37)$ & \\
\hline \multicolumn{10}{|c|}{ Exposure assessment: blood ARA level } \\
\hline \multirow[t]{4}{*}{$\begin{array}{l}\text { Kuriki et al. } \\
2006 \text { [38] }\end{array}$} & \multirow[t]{4}{*}{$\begin{array}{l}\text { Survey, Japan, 2002- } \\
\text { 2004, case-control } \\
\text { design }\end{array}$} & \multirow{4}{*}{$\begin{array}{l}74 \text { CRC patients, } 221 \\
\text { controls, aged } 20-80 \\
\text { without history of cancer } \\
\text { or current diseases, } 1 \text { case } \\
\text { matched with } 3 \text { controls } \\
\text { by age, sex, season of } \\
\text { blood collection }\end{array}$} & \multirow{4}{*}{$\begin{array}{l}\text { Erythrocyte } \\
\text { phospholipids, } \\
\text { GC analysis } \\
\text { blinded to } \\
\text { case-control } \\
\text { status, } \\
\text { precision } \\
\text { indicated }\end{array}$} & \multirow[t]{4}{*}{$\begin{array}{l}\text { Histological } \\
\text { diagnosis }\end{array}$} & \multirow{4}{*}{$\begin{array}{l}\text { BMI, habitual exercise, } \\
\text { alcohol intake, smoking } \\
\text { status, green-yellow } \\
\text { vegetable intake, family } \\
\text { history of CRC }\end{array}$} & \multirow[t]{4}{*}{22} & $\begin{array}{l}\text { ARA } \\
\text { composition, } \\
\text { mol\%, tertile }\end{array}$ & OR $(95 \% \mathrm{Cl})$ & Ptrend \\
\hline & & & & & & & $\mathrm{T} 1:<8.625$ & 1.00 & $<0.05$ \\
\hline & & & & & & & $\begin{array}{l}\text { T2: } 8.625- \\
10.178\end{array}$ & $0.91(0.48-1.73)$ & \\
\hline & & & & & & & T3: $>10.178$ & $0.42(0.18-0.95)$ & \\
\hline \multicolumn{10}{|c|}{ Study design: case-control study (temporal relationship among exposure and outcome is unclear) } \\
\hline \multicolumn{10}{|c|}{ Exposure assessment: dietary intake } \\
\hline \multirow[t]{4}{*}{$\begin{array}{l}\text { Busstra et al. } \\
2003 \text { [39] }\end{array}$} & \multirow[t]{4}{*}{$\begin{array}{l}\text { Survey, Netherlands, } \\
\text { 1995-1998, case-control } \\
\text { design }\end{array}$} & \multirow{4}{*}{$\begin{array}{l}52 \text { CRC patients, } 57 \\
\text { controls, aged under } 75 \\
\text { without history of CRC, } \\
\text { colon resection, polyposis } \\
\text { coli, inflammatory bowel } \\
\text { disease, included subjects } \\
\text { with familial HNPCC, } \\
\text { matching not indicated }\end{array}$} & \multirow{4}{*}{$\begin{array}{l}\text { FFQ } \\
\text { developed for } \\
\text { the Dutch } \\
\text { cohorts of the } \\
\text { EPIC study, } 178 \\
\text { items, } \\
\text { validated } \\
\text { against } 12 \times \\
\text { 24-HDR }\end{array}$} & \multirow[t]{4}{*}{$\begin{array}{l}\text { Histological } \\
\text { diagnosis }\end{array}$} & \multirow[t]{4}{*}{$\begin{array}{l}\text { Age, total energy intake, } \\
\text { sex, familial background of } \\
\text { HNPCC }\end{array}$} & \multirow[t]{4}{*}{13} & $\begin{array}{l}\text { Dietary ARA } \\
\text { intake, g/day, } \\
\text { tertile }\end{array}$ & OR $(95 \% \mathrm{Cl})$ & Ptrend \\
\hline & & & & & & & $\mathrm{T} 1:<0.02$ & 1.0 & 0.37 \\
\hline & & & & & & & T2: $0.02-0.04$ & $1.3(0.4-3.9)$ & \\
\hline & & & & & & & T3: $\geq 0.04$ & $0.6(0.2-1.8)$ & \\
\hline
\end{tabular}




\begin{tabular}{|c|c|c|c|c|c|c|c|c|c|}
\hline \multicolumn{10}{|c|}{ Exposure assessment: blood ARA level } \\
\hline \multirow[t]{11}{*}{$\begin{array}{l}\text { Ghadimi et al. } \\
2008 \text { [40] }\end{array}$} & \multirow[t]{11}{*}{$\begin{array}{l}\text { Survey, Japan, 1997- } \\
2003 \text {, case-control } \\
\text { design }\end{array}$} & \multirow{11}{*}{$\begin{array}{l}203 \text { CRA patients, } 179 \\
\text { controls (negative faecal } \\
\text { occult blood test), } \\
\text { matching not indicated }\end{array}$} & \multirow{11}{*}{$\begin{array}{l}\text { Serum fatty } \\
\text { acids (fasting } \\
\text { blood), GC } \\
\text { analysis, } \\
\text { precision } \\
\text { indicated }\end{array}$} & \multirow[t]{11}{*}{$\begin{array}{l}\text { Histological } \\
\text { diagnosis }\end{array}$} & \multirow{11}{*}{$\begin{array}{l}\text { Age, BMl, family history of } \\
\text { CRA or CRC, history of } \\
\text { diabetes, smoking status, } \\
\text { alcohol intake, physical } \\
\text { activity, season of data } \\
\text { collection }\end{array}$} & \multirow[t]{11}{*}{18} & $\begin{array}{l}\text { ARA } \\
\text { concentration, } \\
\text { mg/dl, quartile }\end{array}$ & OR $(95 \% \mathrm{Cl})$ & Ptrend \\
\hline & & & & & & & Men: & Men: & Men: \\
\hline & & & & & & & Q1:<17.40 & 1.00 & 0.104 \\
\hline & & & & & & & Q2:17.40-19.90 & $0.60(0.21-1.68)$ & Women: \\
\hline & & & & & & & Q3:19.91-22.50 & $0.58(0.21-1.60)$ & 0.001 \\
\hline & & & & & & & Q4: $>22.50$ & $0.52(0.19-1.42)$ & \\
\hline & & & & & & & Women: & Women: & Women: \\
\hline & & & & & & & Q1:<18.05 & 1.00 & 0.001 \\
\hline & & & & & & & Q2:18.05-20.50 & $0.49(0.19-1.24)$ & \\
\hline & & & & & & & Q3:20.51-22.38 & $0.11(0.28-0.45)$ & \\
\hline & & & & & & & Q4:>22.38 & $0.11(0.03-0.43)$ & \\
\hline \multirow[t]{6}{*}{$\begin{array}{l}\text { Baró et al. } \\
1998 \text { [41] }\end{array}$} & \multirow[t]{6}{*}{ Survey, Spain } & \multirow[t]{6}{*}{$\begin{array}{l}17 \text { CRC patients aged } 35- \\
82,12 \text { controls aged } 33-81 \\
\text { with no malignant } \\
\text { diseases, matched by age, } \\
\text { resident area }\end{array}$} & \multirow{6}{*}{$\begin{array}{l}\text { Plasma and } \\
\text { erythrocyte } \\
\text { fatty acids } \\
\text { (fasting blood), } \\
\text { GC analysis, } \\
\text { precision not } \\
\text { indicated }\end{array}$} & \multirow[t]{6}{*}{ Not shown } & \multirow[t]{6}{*}{ None } & \multirow[t]{6}{*}{12} & $\begin{array}{l}\text { Plasma ARA } \\
\text { concentration, } \\
\text { mg/dl, mean } \\
\text { (SEM) }\end{array}$ & $\begin{array}{l}\text { Plasma ARA } \\
\text { concentration, } \\
\text { mg/dl, mean } \\
\text { (SEM) }\end{array}$ & $P$ \\
\hline & & & & & & & Case: & Control: & Plasma: \\
\hline & & & & & & & $18.59(1.31)$ & $21.31(1.22)$ & $\begin{array}{l}\text { Not } \\
\text { significant }\end{array}$ \\
\hline & & & & & & & $\begin{array}{l}\text { Erythrocyte } \\
\text { ARA } \\
\text { composition\%, } \\
\text { mean(SEM) }\end{array}$ & $\begin{array}{l}\text { Erythrocyte } \\
\text { ARA } \\
\text { composition\%, } \\
\text { mean(SEM) }\end{array}$ & Erythrocyte: \\
\hline & & & & & & & Case: & Control: & \\
\hline & & & & & & & $14.61(0.24)$ & $13.50(0.40)$ & $\begin{array}{l}\text { Not } \\
\text { significant }\end{array}$ \\
\hline \multirow[t]{3}{*}{$\begin{array}{l}\text { Neoptolemos } \\
\text { et al. } 1990 \\
{[42]}\end{array}$} & \multirow[t]{3}{*}{ Survey, UK } & \multirow{3}{*}{$\begin{array}{l}32 \text { CRC patients, } 42 \\
\text { controls admitted for } \\
\text { elective operations for } \\
\text { benign without DM, } \\
\text { metabolic disorders, blood } \\
\text { transfusions, matched by } \\
\text { age, sex, admittance }\end{array}$} & \multirow{3}{*}{$\begin{array}{l}\text { Erythrocyte } \\
\text { phospholipids } \\
\text { (fasting blood), } \\
\text { GC analysis, } \\
\text { precision not } \\
\text { indicated }\end{array}$} & \multirow[t]{3}{*}{ Not shown } & \multirow[t]{3}{*}{ None } & \multirow[t]{3}{*}{13} & $\begin{array}{l}\text { ARA } \\
\text { composition\%, } \\
\text { median(range) }\end{array}$ & $\begin{array}{l}\text { ARA } \\
\text { composition\%, } \\
\text { median(range) }\end{array}$ & $P$ \\
\hline & & & & & & & Case: & Control: & \\
\hline & & & & & & & $20.7(12.8-48.9)$ & $18.0(0.0-47.3)$ & $\begin{array}{l}\text { Not } \\
\text { significant }\end{array}$ \\
\hline
\end{tabular}


Table 1 Summary of observational studies on the association between ARA and risk of colorectal cancer (Continued)

\begin{tabular}{|c|c|c|c|c|c|c|c|c|c|}
\hline \multirow[t]{3}{*}{$\begin{array}{l}\text { Neoptolemos } \\
\text { et al. } 1988 \\
\text { [43] }\end{array}$} & \multirow[t]{3}{*}{ Survey, UK } & \multirow{3}{*}{$\begin{array}{l}49 \text { CRC patients aged 49- } \\
92,49 \text { controls with } \\
\text { benign diaseases aged 48- } \\
\text { 90, matched by age, sex }\end{array}$} & \multirow{3}{*}{$\begin{array}{l}\text { Erythrocyte } \\
\text { phospholipids } \\
\text { (fasting blood), } \\
\text { GC analysis, } \\
\text { precision not } \\
\text { indicated }\end{array}$} & \multirow[t]{3}{*}{ Not shown } & \multirow[t]{3}{*}{ None } & \multirow[t]{3}{*}{12} & $\begin{array}{l}\text { ARA } \\
\text { composition\%, } \\
\text { median(range) }\end{array}$ & $\begin{array}{l}\text { ARA } \\
\text { composition\%, } \\
\text { median(range) }\end{array}$ & \multirow[t]{2}{*}{$P$} \\
\hline & & & & & & & Case: & Control: & \\
\hline & & & & & & & $21.8(15.3-28.4)$ & $23.5(13.8-32.8)$ & 0.043 \\
\hline \multicolumn{10}{|c|}{ Exposure assessment: tissue ARA level } \\
\hline \multirow[t]{4}{*}{$\begin{array}{l}\text { Busstra et al. } \\
2003 \text { [39] }\end{array}$} & \multirow[t]{4}{*}{$\begin{array}{l}\text { Survey, Netherlands, } \\
\text { 1995-1998, case-control } \\
\text { design }\end{array}$} & \multirow{4}{*}{$\begin{array}{l}52 \text { CRC patients, } 57 \\
\text { controls, aged under } 75 \\
\text { without history of CRC, } \\
\text { colon resection, polyposis } \\
\text { coli, inflammatory bowel } \\
\text { disease, included subjects } \\
\text { with familial HNPCC, } \\
\text { matching not indicated }\end{array}$} & \multirow{4}{*}{$\begin{array}{l}\text { Buttock } \\
\text { adipose tissue } \\
\text { fatty acids, GC } \\
\text { analysis, } \\
\text { precision not } \\
\text { indicated }\end{array}$} & \multirow[t]{4}{*}{$\begin{array}{l}\text { Histological } \\
\text { diagnosis }\end{array}$} & \multirow[t]{4}{*}{$\begin{array}{l}\text { Age, total energy intake, } \\
\text { sex, familial background of } \\
\text { HNPCC }\end{array}$} & \multirow[t]{4}{*}{13} & $\begin{array}{l}\text { ARA } \\
\text { composition } \\
\text { mass\%, tertile }\end{array}$ & $\mathrm{OR}(95 \% \mathrm{Cl})$ & Ptrend \\
\hline & & & & & & & $\mathrm{T} 1:<0.35$ & 1.0 & \multirow[t]{3}{*}{0.42} \\
\hline & & & & & & & T2: $0.35-0.45$ & $2.6(0.7-8.5)$ & \\
\hline & & & & & & & $\mathrm{T} 3: \geq 0.45$ & $1.7(0.5-5.8)$ & \\
\hline \multicolumn{10}{|c|}{ Study design: cross-sectional study } \\
\hline \multicolumn{10}{|c|}{ Exposure assessment: blood ARA level } \\
\hline \multirow[t]{3}{*}{$\begin{array}{l}\text { Almendingen } \\
\text { et al. } 2006 \\
\text { [44] }\end{array}$} & \multirow[t]{3}{*}{ Survey, Norway } & \multirow[t]{3}{*}{$\begin{array}{l}38 \text { FAP patients aged 24- } \\
70 \text { (all colectomized), } 160 \\
\text { healthy controls aged } 21- \\
66\end{array}$} & \multirow{3}{*}{$\begin{array}{l}\text { Serum } \\
\text { phospholipids } \\
\text { (fasting blood), } \\
\text { GC analysis, } \\
\text { precision } \\
\text { indicated }\end{array}$} & \multirow[t]{3}{*}{$\begin{array}{l}\text { Diagnosis by } \\
\text { endoscopy and } \\
\text { histology }\end{array}$} & \multirow[t]{3}{*}{ None } & \multirow[t]{3}{*}{17} & $\begin{array}{l}\text { ARA } \\
\text { composition } \\
\text { weight\%, } \\
\text { mean(SD) }\end{array}$ & $\begin{array}{l}\text { ARA } \\
\text { composition } \\
\text { weight\%, } \\
\text { mean(SD) }\end{array}$ & \multirow[b]{3}{*}{$\leq 0.0001$} \\
\hline & & & & & & & Case: & Control: & \\
\hline & & & & & & & 10.96(1.85) & $7.26(1.51)$ & \\
\hline \multirow[t]{4}{*}{$\begin{array}{l}\text { Fernández- } \\
\text { Bañares et al. } \\
1996 \text { [45] }\end{array}$} & \multirow[t]{4}{*}{ Survey, Spain } & \multirow{4}{*}{$\begin{array}{l}22 \text { colonic cancer patients, } \\
27 \text { colonic adenoma } \\
\text { patients, } 12 \text { controls with } \\
\text { benign diseases, no } \\
\text { significant differences in } \\
\text { sex and age }\end{array}$} & \multirow{4}{*}{$\begin{array}{l}\text { Plasma } \\
\text { phospholipids } \\
\text { (fasting blood), } \\
\text { GC analysis, } \\
\text { precision not } \\
\text { indicated }\end{array}$} & \multirow[t]{4}{*}{$\begin{array}{l}\text { Total fibreoptic } \\
\text { colonoscopy }\end{array}$} & \multirow[t]{4}{*}{ None } & \multirow[t]{4}{*}{13} & $\begin{array}{l}\text { ARA } \\
\text { composition\%, } \\
\text { mean(SEM) } \\
\text { Carcinoma: }\end{array}$ & $\begin{array}{l}\text { ARA } \\
\text { composition\%, } \\
\text { mean(SEM) } \\
\text { Controls: }\end{array}$ & $\mathrm{P}$ \\
\hline & & & & & & & $9.38(0.37)$ & 10.2(0.32) & Not \\
\hline & & & & & & & Adenoma: & & \\
\hline & & & & & & & $9.95(0.49)$ & & \\
\hline $\begin{array}{l}\text { Hietanen } \\
\text { et al. } 1994 \\
\text { [46] }\end{array}$ & $\begin{array}{l}\text { Survey, UK, cross- } \\
\text { sectional design }\end{array}$ & $\begin{array}{l}20 \text { colon cancer patients } \\
\text { aged } 38-84 \text {, controls, } \\
\text { matched by age, sex, } \\
\text { smoking status }\end{array}$ & $\begin{array}{l}\text { Erythrocyte } \\
\text { phospholipids } \\
\text { (fasting blood), } \\
\text { GC analysis, }\end{array}$ & Not shown & None & 8 & $\begin{array}{l}\text { ARA } \\
\text { concentration, } \\
\mathrm{mg} / \mathrm{dl} \text {, mean } \\
\text { (SD) }\end{array}$ & $\begin{array}{l}\text { ARA } \\
\text { concentration, } \\
\text { mg/dl, } \\
\text { mean(SD) }\end{array}$ & $P$ \\
\hline & & & $\begin{array}{l}\text { precision not } \\
\text { indicated }\end{array}$ & & & & Case: & Control: & \\
\hline & & & & & & & 18.5(0.6) & $20.2(0.5)$ & $<0.05$ \\
\hline
\end{tabular}

20.2(0.5) 
Table 1 Summary of observational studies on the association between ARA and risk of colorectal cancer (Continued)

\begin{tabular}{|c|c|c|c|c|c|c|c|c|c|}
\hline \multicolumn{10}{|c|}{ Exposure assessment: tissue ARA level } \\
\hline \multirow[t]{4}{*}{$\begin{array}{l}\text { Fernández- } \\
\text { Bañares et al. } \\
1996 \text { [45] }\end{array}$} & \multirow[t]{4}{*}{ Survey, Spain } & \multirow[t]{4}{*}{$\begin{array}{l}15 \text { colonic cancer patients, } \\
21 \text { colonic adenoma } \\
\text { patients, } 8 \text { controls with } \\
\text { benign diseases }\end{array}$} & \multirow{4}{*}{$\begin{array}{l}\text { Normal colon } \\
\text { mucosa fatty } \\
\text { acids, GC } \\
\text { analysis, } \\
\text { precision not } \\
\text { indicated }\end{array}$} & \multirow[t]{4}{*}{$\begin{array}{l}\text { Total fibreoptic } \\
\text { colonoscopy }\end{array}$} & \multirow[t]{4}{*}{ None } & \multirow[t]{4}{*}{13} & $\begin{array}{l}\text { ARA } \\
\text { composition\%, } \\
\text { mean(SEM) } \\
\text { Carcinoma: }\end{array}$ & $\begin{array}{l}\text { ARA } \\
\text { composition\%, } \\
\text { mean (SEM) } \\
\text { Controls: }\end{array}$ & $P$ \\
\hline & & & & & & & $10.9(0.57)$ & $11.4(0.88)$ & \multirow{3}{*}{$\begin{array}{l}\text { Not } \\
\text { significant }\end{array}$} \\
\hline & & & & & & & Adenoma: & & \\
\hline & & & & & & & $12.3(0.55)$ & & \\
\hline \multirow[t]{4}{*}{$\begin{array}{l}\text { Berry et al. } \\
1986 \text { [47] }\end{array}$} & \multirow[t]{4}{*}{ Survey, Israel, 1982-1985 } & \multirow{4}{*}{$\begin{array}{l}155 \text { consecutive } \\
\text { colonoscopies ( } 53 \\
\text { carcinoma, } 34 \text { benign } \\
\text { neoplastic polyps, } 68 \\
\text { controls) }\end{array}$} & \multirow{4}{*}{$\begin{array}{l}\text { Buttock } \\
\text { adipose tissue } \\
\text { fatty acids, GC } \\
\text { analysis, } \\
\text { precision } \\
\text { indicated }\end{array}$} & \multirow[t]{4}{*}{$\begin{array}{l}\text { Histological } \\
\text { diagnosis }\end{array}$} & \multirow[t]{4}{*}{ None } & \multirow[t]{4}{*}{13} & $\begin{array}{l}\text { ARA } \\
\text { composition\%, } \\
\text { mean (SD) } \\
\text { Carcinoma: }\end{array}$ & $\begin{array}{l}\text { ARA } \\
\text { composition\%, } \\
\text { mean (SD) } \\
\text { Controls: }\end{array}$ & $P$ \\
\hline & & & & & & & $0.54(0.2)$ & $0.55(0.2)$ & \multirow{3}{*}{$\begin{array}{l}\text { Not } \\
\text { significant }\end{array}$} \\
\hline & & & & & & & $\begin{array}{l}\text { Benign } \\
\text { neoplastic } \\
\text { polyps: }\end{array}$ & & \\
\hline & & & & & & & $0.52(0.2)$ & & \\
\hline
\end{tabular}

24-HDR 24-h dietary recall, ARA Arachidonic acid, BMI Body mass index, CRA Colorectal adenoma, CRC Colorectal cancer, DM Diabetes mellitus, FAP Familial adenomatous polyposis, FFQ Food frequency questionnaire, GC Gas chromatography, HNPCC Hereditary non-polyposis colorectal cancer, HRT Hormone replacement therapy, JACC Japan Collaborative Cohort, NMSC Nonmelanoma skin cancer, NSAIDs Nonsteroidal antiinflammatory drugs, OR Odds ratio, PHS Physician's health study, RR Relative risk, SWHS Shanghai Women's Health Study, UK United Kingdom, USA United States of America, WHS Women's Health Study, WR Weighed dietary record.

*Result of the critical evaluation carried out using the STROBE tool. 
and case-control studies were adjusted for well-known potential confounders, such as family history, body weight and smoking, and specific factors for colorectal cancer, such as body mass index (BMI), physical activity, alcohol drinking and total energy. No confounding factors were adjusted for in eight articles.

Dietary ARA intake was estimated in two cohort studies and four case-control studies. Median dietary ARA intake ranged widely from 0.008 to $0.15 \mathrm{~g} /$ day, or from $0.04 \%$ to $0.07 \%$ of energy. Two articles reported a significant increase in colorectal cancer risk. Muff et al. indicated that colorectal cancer risk was significantly increased in the third and fourth quintiles of ARA intake, and that the overall trend was significant ( $\mathrm{P}$ for trend $=0.03$ ). Nkondjock et al. reported significantly increased colorectal cancer risk in the third and fourth quartiles and significance in the overall trend ( $\mathrm{P}$ for trend $=0.001$ ).

In seven case-control studies and three cross-sectional studies, the exposure was indicated as blood ARA levels. The precision of blood analysis was mentioned in only four reports, and blinded fatty acid measurement was conducted in only three reports. Five articles showed a significant trend of decreasing colorectal cancer risk or a significant difference of blood ARA levels in cancer subjects. Kuriki et al. found that colorectal cancer risk was significantly decreased in the highest tertile of erythrocyte ARA levels, and that the overall trend was significant ( $\mathrm{P}$ for trend $<0.05$ ). The remaining four reports, Ghadimi et al., Hietanen et al., Neoptolemos et al. (1988), and Almending et al., were a case-control study with little temporal information between exposure and outcome or a cross-sectional study.

One case-control study with little temporal information between exposure and outcome and two crosssectional studies investigated tissue ARA levels. The precision of tissue analysis was mentioned in only one article, and none reported masking of disease status. Their reporting quality was generally low.

\section{Skin cancer}

Only three articles were included in the present systematic review. Major characteristics are shown in Table 2 [48-50]. Their exposure assessment and subjects' characteristics were too diverse to be compared to each other.

\section{Breast cancer}

Major characteristics are shown in Table 3 [29,46,51-66]. Five articles did not provide sufficient information about the methodology of outcome measurement. In addition to general confounding factors, specific factors for breast cancer, such as reproductive factors and history of benign breast disease, were considered in some articles; however, no confounding factors were investigated in eight articles.
Dietary ARA intake was estimated in one cohort study and three case-control studies. These four showed no significant change in breast cancer risk except in the second quartile of ARA intake in the report by Nkondjock et al.

Six case-control studies and three cross-sectional studies investigated blood ARA levels. The precision of blood analysis was reported in only five articles, and blinded fatty acid measurement was conducted in only two articles. Three articles indicated significant differences in breast cancer risk; however, they were a casecontrol study with little temporal information between exposure and outcome or a cross-sectional study. Aro et al. reported significantly increased breast cancer risk in the highest quintile of serum ARA in post-menopausal women. The reporting quality of the remaining two articles, those by Zaridze et al. and Williams et al., was quite low.

Five case-control studies and two cross-sectional studies examined tissue ARA levels. The precision of tissue analysis was mentioned in only three articles, and only in one report fatty acids measurement was performed in a blinded fashion. A significant change in breast cancer risk or a significant difference in tissue ARA level was not found, except for breast tissue triglyceride ARA levels in a report by Zhu et al. and breast tissue phosphatidylcholine ARA levels in a report by Williams et al.

\section{Prostate cancer}

Major characteristics are shown in Table 4 [46,67-81]. Four articles did not provide sufficient information about the methodology of outcome measurement. As well as well-known confounding factors, specific factors for prostate cancer, for instance BMI, physical activity, and total energy, were considered in some articles; however, no confounding factors were adjusted for in seven articles.

One cohort study and three case-control studies examined dietary ARA intake. They showed no significant change in prostate cancer risk according to increased ARA intake.

Blood ARA levels were estimated in nine case-control studies and three cross-sectional studies. The precision of blood analysis was mentioned in only five articles, and masking of disease status was conducted in only four. Ukori et al. (2010) reported that prostate cancer risk of African-Americans decreased in the fourth quartile of blood ARA level, and that the overall trend was significant ( $\mathrm{P}$ for trend $<0.05$ ). A significant change in prostate cancer risk or a significant difference in blood ARA levels was not found in the other 11 articles.

Three cross-sectional studies examined tissue ARA levels. All of them reported significant decreases of tissue ARA levels in cancer subjects; however, their reporting quality was generally quite low. None of them mentioned the precision of tissue analysis and masking of groups. 
Table 2 Summary of observational studies on the association between ARA and risk of skin cancer

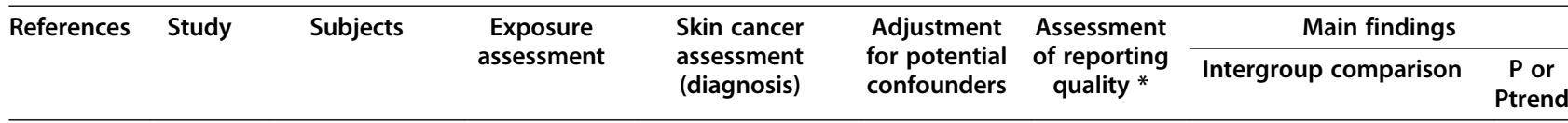

Study design: case-control study (temporal relationship among exposure and outcome is unclear)

Exposure assessment: dietary intake

\begin{tabular}{|c|c|c|c|c|c|c|c|c|c|}
\hline $\begin{array}{l}\text { Hakim } \\
\text { et al. } 2000 \\
\text { [48] }\end{array}$ & $\begin{array}{l}\text { Survey, } \\
\text { USA, } \\
\text { case- } \\
\text { control } \\
\text { design }\end{array}$ & $\begin{array}{l}301 \\
\text { nonmetastatic } \\
\text { skin SCC } \\
\text { patients aged } \\
\geq 30,267 \\
\text { population- } \\
\text { baseed controls } \\
\text { with no prior } \\
\text { history of skin } \\
\text { cancer, matched } \\
\text { by age, sex }\end{array}$ & $\begin{array}{l}\text { 24-HDR of } 4 \\
\text { days, validated }\end{array}$ & $\begin{array}{l}\text { Histopathologically } \\
\text { diagnosed skin SCC } \\
\text { selected from } \\
\text { Southeastern } \\
\text { Arizona Skin } \\
\text { Cancer Registry }\end{array}$ & $\begin{array}{l}\text { Age, sex, total } \\
\text { energy intake, } \\
\text { history of } \\
\text { diagnosed } \\
\text { actinic } \\
\text { keratosis, } \\
\text { tanning } \\
\text { ability, freckles } \\
\text { on arms, use } \\
\text { of sunscreen }\end{array}$ & 22 & $\begin{array}{l}\text { Dietary ARA } \\
\text { intake, g/ } \\
\text { day, tertile } \\
\text { T1: } \leq 0.1 \\
\text { T2: } 0.11-0.20 \\
\text { T3: }>0.20\end{array}$ & $\begin{array}{l}1.00 \\
0.86(0.57- \\
1.29) \\
0.70(0.46- \\
1.08)\end{array}$ & Ptreno \\
\hline
\end{tabular}

Exposure assessment: blood ARA level

\begin{tabular}{|c|c|c|c|c|c|c|c|c|c|}
\hline $\begin{array}{l}\text { Harris et al. } \\
2005 \text { [49] }\end{array}$ & $\begin{array}{l}\text { Survey, } \\
\text { USA, } \\
\text { case- } \\
\text { control } \\
\text { design }\end{array}$ & $\begin{array}{l}336 \\
\text { nonmetastatic } \\
\text { skin SCC } \\
\text { patients aged } \\
\geq 30,321 \\
\text { controls with no } \\
\text { prior history of } \\
\text { skin cancer, } \\
\text { matched by age, } \\
\text { sex, race }\end{array}$ & $\begin{array}{l}\text { Erythrocyte } \\
\text { fatty acids } \\
\text { (fasting } \\
\text { blood), GC } \\
\text { analysis, } \\
\text { precision } \\
\text { indicated }\end{array}$ & $\begin{array}{l}\text { Histopathologically } \\
\text { diagnosed skin SCC } \\
\text { selected from } \\
\text { Southeastern } \\
\text { Arizona Skin } \\
\text { Cancer Registry }\end{array}$ & $\begin{array}{l}\text { Age, sex, lab, } \\
\text { tanning } \\
\text { ability, freckles } \\
\text { on arms, } \\
\text { exclusion of } \\
94 \text { controls } \\
\text { with history of } \\
\text { prior actinic } \\
\text { keratosis }\end{array}$ & 25 & $\begin{array}{l}\text { ARA } \\
\text { composition } \\
\text { weight\%, } \\
\text { quartile } \\
\text { Q1 } \\
\text { Q2 } \\
\text { Q3 } \\
\text { Q4 }\end{array}$ & $\begin{array}{l}1.00 \\
1.61(0.92- \\
2.80) \\
1.40(0.79- \\
2.49) \\
2.38(1.37- \\
4.12)\end{array}$ & $\begin{array}{l}\text { Not } \\
\text { shown }\end{array}$ \\
\hline \multicolumn{10}{|c|}{ Exposure assessment: tissue ARA level } \\
\hline $\begin{array}{l}\text { Mackie } \\
\text { et al. } 1987 \\
{[50]}\end{array}$ & $\begin{array}{l}\text { Survey, } \\
\text { Australia, } \\
1984- \\
1985\end{array}$ & $\begin{array}{l}100 \text { primary } \\
\text { melanoma } \\
\text { patients, } 100 \\
\text { controls with no } \\
\text { history of } \\
\text { malignant skin } \\
\text { tumor, matched } \\
\text { by age, sex, race }\end{array}$ & $\begin{array}{l}\text { Subcutaneous } \\
\text { adipose tissue } \\
\text { triglyceride, } \\
\text { GC analysis } \\
\text { blinded to } \\
\text { case-control } \\
\text { status, } \\
\text { precision not } \\
\text { indicated }\end{array}$ & $\begin{array}{l}\text { Selected from } \\
\text { Sydney Melanoma } \\
\text { Unit }\end{array}$ & None & 10 & $\begin{array}{l}\text { ARA } \\
\text { composition } \\
\% \text {, mean } \\
\text { Case: } \\
0.41\end{array}$ & $\begin{array}{l}\text { ARA } \\
\text { composition } \\
\% \text {, mean } \\
\text { Control: } \\
0.28\end{array}$ & $<0.001$ \\
\hline
\end{tabular}

24-HDR: 24-h dietary recall, ARA Arachidonic, GC Gas chromatography, OR Odds Ratio, SCC Squamous cell caricinoma, USA United States of America. *Result of the critical evaluation carried out using the STROBE tool.

\section{Discussion}

In the present review, we systematically reviewed observational studies investigating the association between ARA and cancer of six organs in free-living populations. Fifty-two eligible articles were obtained from our search strategy, and 31 out of the 52 articles were identified from hand searches for references (Figure 1). Thus, reference searching serves an important role in comprehensive literature searches. This pointed out the characteristics of the reporting style of the observational studies for ARA and cancer risk.

Among the 31 eligible articles from reference searches, 22 were not recognised by our PubMed search formula due to keywords related to "exposure", three were not recognised due to keywords related to "study types", and six were not recognised due to both. For "exposure" terms, 26 articles could be identified by the addition of the search term "fatty". The remaining two articles related to the term "exposure" reported fatty acid compositions of tissues only. In the case of "study type" terms, none of the nine articles used a general study design word (i.e., cohort, case-control, or cross-sectional), although the STROBE statement recommends that authors should indicate the study design with a commonly used term in the title or abstract. These reporting characteristics made it difficult to effectively search for observational studies with a focus on individual fatty acids such as ARA. We therefore adopted the search strategy described above.

The findings from articles for colorectal cancer differ depending on the methodology of ARA exposure assessment. A positive dose-response relationship between dietary ARA intake and colorectal cancer was indicated 
Table 3 Summary of observational studies on the association between ARA and risk of breast cancer

\begin{tabular}{|c|c|c|c|c|c|c|c|c|c|}
\hline \multirow[t]{2}{*}{ References } & \multirow[t]{2}{*}{ Study } & \multirow[t]{2}{*}{ Subjects } & \multirow{2}{*}{$\begin{array}{l}\text { Exposure } \\
\text { Assessment }\end{array}$} & \multirow{2}{*}{$\begin{array}{c}\text { Breast cancer } \\
\text { assessment } \\
\text { (diagnosis) }\end{array}$} & \multirow{2}{*}{$\begin{array}{c}\text { Adjustment for } \\
\text { potential confounders }\end{array}$} & \multirow{2}{*}{$\begin{array}{l}\text { Assessment } \\
\text { of reporting } \\
\text { quality * }\end{array}$} & \multicolumn{3}{|c|}{ Main findings } \\
\hline & & & & & & & Intergroup & comparison & P or Ptrend \\
\hline \multicolumn{10}{|c|}{$\begin{array}{l}\text { Study design: cohort study } \\
\text { Exposure assessment: dietary intake }\end{array}$} \\
\hline $\begin{array}{l}\text { Holmes } \\
\text { et al. } 1999 \\
\text { [51] }\end{array}$ & $\begin{array}{l}\text { NHS, USA, 1976- } \\
\text { 1994, prospective } \\
\text { cohort design (14 } \\
\text { year biennial follow- } \\
\text { up, follow-up rate = } \\
95 \%)\end{array}$ & $\begin{array}{l}88,795 \text { female nurses } \\
\text { aged } 30-55 \text {, no prior } \\
\text { history of cancer other } \\
\text { than nonmelanoma } \\
\text { skin cancer }\end{array}$ & $\begin{array}{l}\text { Semiquantitative } \\
\text { FFQ, } 131 \text { items, } \\
\text { validated against } \\
2 \times 7 \text {-day WR }\end{array}$ & $\begin{array}{l}\text { Self-reported } \\
\text { physician diagnosis, } \\
\text { deaths identified by } \\
\text { family member of } \\
\text { participants, postal } \\
\text { services and } \\
\text { National Death } \\
\text { Index, } \\
\text { supplemented by } \\
\text { medical record }\end{array}$ & $\begin{array}{l}\text { Total energy intake, } \\
\text { age, energy-adjusted } \\
\text { vitamin A intake, } \\
\text { alcohol intake, time } \\
\text { period, height, parity, } \\
\text { age at first birth, weight } \\
\text { change, BMl, age at } \\
\text { menopause, } \\
\text { menopausal status, use } \\
\text { of HRT, family history, } \\
\text { benign breast disease, } \\
\text { age at menarche }\end{array}$ & 19 & $\begin{array}{l}\text { \%energy } \\
\text { increment of } \\
\text { dietary ARA } \\
\text { intake per day } \\
0.03\end{array}$ & $\begin{array}{l}\operatorname{RR}(95 \% \mathrm{Cl}) \\
1.05(1.00-1.10)\end{array}$ & $\begin{array}{l}\text { P } \\
\text { Not shown }\end{array}$ \\
\hline \multicolumn{10}{|c|}{$\begin{array}{l}\text { Study design: nested case-control study } \\
\text { Exposure assessment: dietary intake }\end{array}$} \\
\hline $\begin{array}{l}\text { Voorrips } \\
\text { et al. } 2002 \\
\text { [52] }\end{array}$ & $\begin{array}{l}\text { NLCS, Netherlands, } \\
\text { 1986-1992 ( } 6.3 \text { years } \\
\text { follow-up), case- } \\
\text { cohort design }\end{array}$ & $\begin{array}{l}941 \text { breast cancer } \\
\text { patients from entire } \\
\text { cohort, 1,598 subcohort } \\
\text { members (selection } \\
\text { criteria not shown), } \\
\text { aged 55-69 at baseline, } \\
\text { no prior history of } \\
\text { cancer other than } \\
\text { nonmelanoma skin } \\
\text { cancer, matching not } \\
\text { indicated }\end{array}$ & $\begin{array}{l}\text { Semiquantitative } \\
\text { FFQ, } 150 \text { items, } \\
\text { validated against } \\
3 \times 3 \text {-day DR }\end{array}$ & $\begin{array}{l}\text { All regional cancer } \\
\text { registries and Dutch } \\
\text { national database } \\
\text { of pathology } \\
\text { reports }\end{array}$ & $\begin{array}{l}\text { Age, history of benign } \\
\text { breast disease, maternal } \\
\text { breast cancer, breast } \\
\text { cancer in one or more } \\
\text { sisters, age at } \\
\text { menarche, age at } \\
\text { menopause, oral } \\
\text { contraceptive use, } \\
\text { parity, age at first birth, } \\
\text { Quetelet index, } \\
\text { educational level, } \\
\text { alcohol intake, smoking } \\
\text { status, total energy } \\
\text { intake, total energy- } \\
\text { adjusted fat intake }\end{array}$ & 19 & $\begin{array}{l}\text { Dietary ARA } \\
\text { intake, g/day, } \\
\text { quintile, median } \\
\text { Q1: } 0.05 \\
\text { Q2: } 0.07 \\
\text { Q3: } 0.09 \\
\text { Q4: } 0.11 \\
\text { Q5: } 0.15\end{array}$ & $\begin{array}{l}\mathrm{RR}(95 \% \mathrm{Cl}) \\
1.00 \\
0.80(0.59-1.07) \\
0.84(0.63-1.13) \\
0.80(0.59-1.08) \\
0.99(0.73-1.34)\end{array}$ & $\begin{array}{l}\text { Ptrend } \\
0.93\end{array}$ \\
\hline \multicolumn{10}{|c|}{ Exposure assessment: blood ARA level } \\
\hline $\begin{array}{l}\text { Saadatian- } \\
\text { Elahi et al. } \\
2002 \text { [29] }\end{array}$ & $\begin{array}{l}\text { NYUWHS, USA, 1985- } \\
1995 \text { (average } 4.3 \\
\text { years follow-up), } \\
\text { nested case-control } \\
\text { design }\end{array}$ & $\begin{array}{l}197 \text { breast cancer } \\
\text { patients, } 197 \text { controls } \\
\text { (free of cancer), aged } \\
\text { 34-65, matched by age, } \\
\text { menopausal status, } \\
\text { date of blood } \\
\text { sampling, number of } \\
\text { blood samplings, day } \\
\text { of menstrual cycle }\end{array}$ & $\begin{array}{l}\text { Serum } \\
\text { phospholipids, } \\
\text { GC analysis, } \\
\text { precision } \\
\text { indicated }\end{array}$ & $\begin{array}{l}\text { Self-reported } \\
\text { physician diagnosis, } \\
\text { combined with } \\
\text { tumor registries, } \\
\text { mortality databases } \\
\text { and review of } \\
\text { clinical and } \\
\text { pathological } \\
\text { documents }\end{array}$ & $\begin{array}{l}\text { Family history, age at } \\
\text { first full-term birth, total } \\
\text { cholesterol, history of } \\
\text { treatment for benign } \\
\text { breast conditions }\end{array}$ & 19 & $\begin{array}{l}\text { ARA } \\
\text { composition\%, } \\
\text { quartile } \\
\text { Q1 } \\
\text { Q2 } \\
\text { Q3 } \\
\text { Q4 }\end{array}$ & $\begin{array}{l}\text { OR(95\% Cl) } \\
1.00 \\
0.79(0.43-1.46) \\
0.99(0.55-1.81) \\
0.81(0.45-1.47)\end{array}$ & $\begin{array}{l}\text { P for the overall } \\
\text { categorial } \\
\text { variable: } \\
0.80 \\
\\
\text { Ptrend with the } \\
\text { score variable } \\
0.66\end{array}$ \\
\hline
\end{tabular}
matching not of menstrual cycle documents 
Table 3 Summary of observational studies on the association between ARA and risk of breast cancer (Continued)

\begin{tabular}{|c|c|c|c|c|c|c|c|c|c|}
\hline $\begin{array}{l}\text { Pala et al. } \\
2001[53]\end{array}$ & $\begin{array}{l}\text { ORDET study, Italy, } \\
1987-1995 \text { (average } \\
5.5 \text { years follow-up) }\end{array}$ & $\begin{array}{l}71 \text { breast cancer } \\
\text { patients, } 141 \text { controls } \\
\text { (free of cancer), } 1 \text { case } \\
\text { matched with } 2 \\
\text { controls by age, } \\
\text { menopausal status at } \\
\text { recruitment, daylight- } \\
\text { saving period at blood } \\
\text { sampling, recruitment } \\
\text { center and date }\end{array}$ & 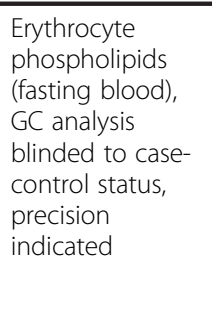 & $\begin{array}{l}\text { Lombardy Cancer } \\
\text { Registry }\end{array}$ & $\begin{array}{l}\text { None (BMI, WHR, age at } \\
\text { menarche, age at first } \\
\text { birth, age at } \\
\text { menopause, months of } \\
\text { lactation, parity and } \\
\text { educational level were } \\
\text { investigated) }\end{array}$ & 23 & $\begin{array}{l}\text { ARA } \\
\text { composition\%, } \\
\text { tertile } \\
\text { T1: }<16.67 \\
\text { T2: } \geq 16.67- \\
<17.94 \\
\text { T3: } \geq 17.94\end{array}$ & $\begin{array}{l}1.00 \\
1.76(0.88-3.53) \\
1.40(0.64-3.10)\end{array}$ & Ptrend \\
\hline $\begin{array}{l}\text { Chajès } \\
\text { et al. } 1999 \\
\text { [54] }\end{array}$ & $\begin{array}{l}\text { Three ongoing } \\
\text { cohort studies in } \\
\text { Sweden, VIP(1986- } \\
\text { 1997), northern } \\
\text { Sweden component } \\
\text { of the WHO MONICA } \\
\text { (1986, } 1990 \text { and } \\
\text { 1994), MSP(1995- } \\
\text { 1997), nested case- } \\
\text { control design }\end{array}$ & $\begin{array}{l}196 \text { breast cancer } \\
\text { patients (VIP 103, } \\
\text { MONICA 9, MSP 84), } \\
388 \text { controls (VIP 214, } \\
\text { MONICA 6, MSP 168), } 1 \\
\text { case matched with } 2 \\
\text { controls by age, age of } \\
\text { blood sample, } \\
\text { sampling center }\end{array}$ & $\begin{array}{l}\text { Serum } \\
\text { phospholipids } \\
\text { (for VIP and } \\
\text { MONICA fasting } \\
\text { blood, for MSP } \\
\text { very little fasting } \\
\text { blood), GC } \\
\text { analysis, } \\
\text { precision } \\
\text { indicated }\end{array}$ & $\begin{array}{l}\text { Regional cancer } \\
\text { registry, National } \\
\text { Cancer Registry, } \\
\text { follow-up for vital } \\
\text { status (death) or } \\
\text { losses to follow-up } \\
\text { determined } \\
\text { through local and } \\
\text { national population } \\
\text { registries }\end{array}$ & $\begin{array}{l}\text { Age at menarche, } \\
\text { parity, age at first full- } \\
\text { term pregnancy, use of } \\
\text { hormones, menopausal } \\
\text { status }\end{array}$ & 19 & $\begin{array}{l}\text { ARA } \\
\text { composition\%, } \\
\text { quartile } \\
\text { Q1 } \\
\text { Q2 } \\
\text { Q3 } \\
\text { Q4 }\end{array}$ & $\begin{array}{l}1.00 \\
0.49(0.24-0.99) \\
0.48(0.22-1.04) \\
0.51(0.24-1.09)\end{array}$ & Ptrend \\
\hline \multicolumn{10}{|c|}{$\begin{array}{l}\text { Study design: case-control study (temporal relationship among exposure and outcome is demonstrated) } \\
\text { Exposure assessment: dietary intake }\end{array}$} \\
\hline $\begin{array}{l}\text { Nkondjock } \\
\text { et al. } 2003 \\
\text { [55] }\end{array}$ & $\begin{array}{l}\text { Survey, Canada, } \\
\text { 1989-1993, case- } \\
\text { control design }\end{array}$ & $\begin{array}{l}414 \text { primary breast } \\
\text { cancer patients aged } \\
35-79,688 \text { controls } \\
\text { (eligibility criteria not } \\
\text { shown), population- } \\
\text { based, matched by age, } \\
\text { language, place of } \\
\text { residence }\end{array}$ & $\begin{array}{l}\text { French version } \\
F F Q,>200 \text { items, } \\
\text { validated against } \\
\text { 7-day FD }\end{array}$ & $\begin{array}{l}\text { Histological } \\
\text { diagnosis }\end{array}$ & $\begin{array}{l}\text { Age at first full-term } \\
\text { pregnancy, smoking } \\
\text { status, family history of } \\
\text { breast cancer, history of } \\
\text { benign breast disease, } \\
\text { marital status, number } \\
\text { of full-term pregnancies, } \\
\text { total energy intake }\end{array}$ & 20 & $\begin{array}{l}\text { Dietary ARA } \\
\text { intake, g/day, } \\
\text { quartile } \\
\text { Q1 } \\
\text { Q2 } \\
\text { Q3 } \\
\text { Q4 }\end{array}$ & $\begin{array}{l}\mathrm{OR}(95 \% \mathrm{Cl}) \\
1.00 \\
0.65(0.44-0.97) \\
1.01(0.70-1.53) \\
0.86(0.58-1.30)\end{array}$ & Ptrend \\
\hline \multicolumn{10}{|c|}{ Exposure assessment: blood ARA level } \\
\hline $\begin{array}{l}\text { Vatten } \\
\text { et al. } 1993 \\
\text { [56] }\end{array}$ & $\begin{array}{l}\text { Janus Serum Bank, } \\
\text { Norway, 1973-1991, } \\
\text { case-control design }\end{array}$ & $\begin{array}{l}87 \text { breast cancer } \\
\text { patients, } 235 \text { controls } \\
\text { with no prior history of } \\
\text { cancer, matched by } \\
\text { age, date of blood } \\
\text { sampling }\end{array}$ & $\begin{array}{l}\text { Serum } \\
\text { phospholipid, GC } \\
\text { analysis blinded } \\
\text { to case-control } \\
\text { state, precision } \\
\text { indicated }\end{array}$ & $\begin{array}{l}\text { National cancer } \\
\text { registry linked to } \\
\text { Janus Serum Bank } \\
\text { donor information }\end{array}$ & None & 20 & $\begin{array}{l}\text { ARA } \\
\text { concentration, } \\
\text { mg/l, mean(SD) } \\
78(30)\end{array}$ & $\begin{array}{l}\text { ARA } \\
\text { concentration, } \\
\text { mg/l, mean(SD) } \\
79(29)\end{array}$ & Not significant \\
\hline \multicolumn{10}{|c|}{ Exposure assessment: tissue ARA level } \\
\hline $\begin{array}{l}\text { London } \\
\text { et al. } 1993 \\
\text { [57] }\end{array}$ & $\begin{array}{l}\text { Survey, USA, 1986- } \\
\text { 1988, case-control } \\
\text { design }\end{array}$ & $\begin{array}{l}\text { Postmenopausal } \\
\text { women, } 380 \text { breast } \\
\text { cancer patients, } 573 \\
\text { controls with breast } \\
\text { abnormality (free of } \\
\text { breast cancer), } \\
\text { matching not indicated }\end{array}$ & $\begin{array}{l}\text { Buttock adipose } \\
\text { tissue fatty acids, } \\
\text { GC analysis, } \\
\text { precision } \\
\text { indicated }\end{array}$ & $\begin{array}{l}\text { Physician diagnosis } \\
\text { (detail not shown) }\end{array}$ & $\begin{array}{l}\text { Age, alcohol intake, age } \\
\text { at first birth, parity, } \\
\text { family history of breast } \\
\text { cancer, age at } \\
\text { menopause, age at } \\
\text { menarche, history of } \\
\text { benign breast disease, } \\
\text { weight }\end{array}$ & 19 & $\begin{array}{l}\text { ARA } \\
\text { composition\%, } \\
\text { quintile } \\
\text { Q1 } \\
\text { Q2 } \\
\text { Q3 } \\
\text { Q4 } \\
\text { Q5 }\end{array}$ & $\begin{array}{l}\text { OR(95\% Cl) } \\
1.0 \\
0.8(0.5-1.2) \\
0.9(0.6-1.5) \\
1.0(0.6-1.6) \\
1.0(0.6-1.6)\end{array}$ & Ptrend \\
\hline
\end{tabular}


Table 3 Summary of observational studies on the association between ARA and risk of breast cancer (Continued)

\begin{tabular}{|c|c|c|c|c|c|c|c|c|c|}
\hline \multicolumn{10}{|c|}{ Study design: case-control study (temporal relationship among exposure and outcome is unclear) } \\
\hline \multirow[t]{4}{*}{$\begin{array}{l}\text { Zhu et al. } \\
1995 \text { [58] }\end{array}$} & $\begin{array}{l}\text { Survey, Finland, 1990- } \\
1992\end{array}$ & $\begin{array}{l}17 \text { premenopausal, } 32 \\
\text { postmenopausal } \\
\text { primary breast cancer }\end{array}$ & $\begin{array}{l}\text { Semiquantitative } \\
\text { FFQ, } 110 \text { items, } \\
\text { validated against }\end{array}$ & $\begin{array}{l}\text { Histological } \\
\text { diagnosis }\end{array}$ & Age, total energy intake & 13 & $\begin{array}{l}\text { Dietary ARA } \\
\text { intake, mg/day, } \\
\text { mean(SD) }\end{array}$ & $\begin{array}{l}\text { Dietary ARA } \\
\text { intake, } \mathrm{mg} / \text { day, } \\
\text { mean(SD) }\end{array}$ & $P$ \\
\hline & & & 14-day DR & & & & & $\begin{array}{l}\text { Premenopausal } \\
\text { control: }\end{array}$ & Premenopausal: \\
\hline & & $\begin{array}{l}\text { postmenopausal } \\
\text { controls with benigh } \\
\text { breast disease }\end{array}$ & & & & & $\begin{array}{l}58(27) \\
\text { Postmenopausal } \\
\text { case: }\end{array}$ & $\begin{array}{l}\text { 163(323) } \\
\text { Postmenopausal } \\
\text { control: }\end{array}$ & $\begin{array}{l}\text { Not significant } \\
\text { Postmenopausal: }\end{array}$ \\
\hline & & $\begin{array}{l}\text { (eligibility criteria not } \\
\text { shown), matching not } \\
\text { indicated }\end{array}$ & & & & & $90(191)$ & $62(26)$ & Not significant \\
\hline \multicolumn{10}{|c|}{ Exposure assessment: blood ARA level } \\
\hline \multirow[t]{8}{*}{$\begin{array}{l}\text { Aro et al. } \\
2000 \text { [59] }\end{array}$} & $\begin{array}{l}\text { Kuopio Breast Cancer } \\
\text { Study, Finland, 1992- } \\
\text { 1995, case-control }\end{array}$ & $\begin{array}{l}195 \text { primary breast } \\
\text { cancer patients aged } \\
25-75,208 \text { controls }\end{array}$ & $\begin{array}{l}\text { Serum fatty acids } \\
\text { (fasting blood), } \\
\text { GC analysis, }\end{array}$ & $\begin{array}{l}\text { Histological } \\
\text { diagnosis }\end{array}$ & $\begin{array}{l}\text { Age, area, age at } \\
\text { menarche, age at first } \\
\text { full-term pregnancy, use }\end{array}$ & 15 & $\begin{array}{l}\text { ARA } \\
\text { composition\%, } \\
\text { quintile, median }\end{array}$ & $\mathrm{OR}(95 \% \mathrm{Cl})$ & Ptrend \\
\hline & design & & $\begin{array}{l}\text { precision } \\
\text { indicated }\end{array}$ & & & & & $\begin{array}{l}\text { Postmenopausal: } \\
1.0\end{array}$ & $\begin{array}{l}\text { Postmenopausal: } \\
\text { Signifncant }\end{array}$ \\
\hline & & $\begin{array}{l}\text { Register, matched by } \\
\text { age, long-term area of }\end{array}$ & & & $\begin{array}{l}\text { history of breast cancer, } \\
\text { history of benign breast }\end{array}$ & & $\begin{array}{l}\text { Q2: } 4.89 \\
\text { Q3: } 5.46\end{array}$ & $\begin{array}{l}1.1(0.4-2.8) \\
2.0(0.8-4.8)\end{array}$ & \\
\hline & & residence & & & disease, educational & & Q4: 6.04 & $2.4(1.0-5.9)$ & \\
\hline & & & & & level, alcohol intake, & & Q5: 7.15 & $3.1(1.3-7.8)$ & P \\
\hline & & & & & $\begin{array}{l}\text { Smoking status, physical } \\
\text { activity, WHR, BMI }\end{array}$ & & $\begin{array}{l}\text { ARA } \\
\text { composition\%, } \\
\text { mean(SD) }\end{array}$ & $\begin{array}{l}\text { ARA } \\
\text { composition\%, } \\
\text { mean(SD) }\end{array}$ & $P$ \\
\hline & & & & & & & $\begin{array}{l}\text { Premenopausal } \\
\text { case: }\end{array}$ & $\begin{array}{l}\text { Premenopausal } \\
\text { control: }\end{array}$ & Premenopausal: \\
\hline & & & & & & & $5.68(1.01)$ & $5.49(1.16)$ & Not significant \\
\hline \multirow[t]{3}{*}{$\begin{array}{l}\text { Zaridze } \\
\text { et al. } 1990 \\
\text { [60] }\end{array}$} & $\begin{array}{l}\text { Survey, now-defunct } \\
\text { Union of Soviet } \\
\text { Socialist Republics, } \\
\text { case-control design }\end{array}$ & $\begin{array}{l}25 \text { premenopausal, } 21 \\
\text { postmenopausal } \\
\text { primary breast cancer } \\
\text { patients, } 20 \\
\text { premenopausal, } 33 \\
\text { postmenopausal } \\
\text { neighborhood controls } \\
\text { (eligibility criteria not }\end{array}$ & $\begin{array}{l}\text { Erythrocyte } \\
\text { phospholipids } \\
\text { (fasting blood), } \\
\text { GC analysis, } \\
\text { precision not } \\
\text { indicated }\end{array}$ & Not shown & None & 11 & $\begin{array}{l}\text { ARA } \\
\text { concentration, } \\
\mu \mathrm{g} / \mathrm{mg} \\
\text { phospholipids, } \\
\text { bisectional, } \\
\text { (Summer- } \\
\text { Autumn/Winter- } \\
\text { Spring) }\end{array}$ & $\operatorname{RR}(95 \% \mathrm{Cl})$ & P \\
\hline & & $\begin{array}{l}\text { shown), matching not } \\
\text { indicated }\end{array}$ & & & & & $\begin{array}{l}\text { Premenopausal: } \\
\leq 11.70 / 9.89 \text { vs }\end{array}$ & $\begin{array}{l}\text { Premenopausal: } \\
0.33(0.08-1.35)\end{array}$ & $\begin{array}{l}\text { Premenopausal: } \\
0.122\end{array}$ \\
\hline & & & & & & & $\begin{array}{l}\text { Postmenopausal: } \\
\leq 11.70 / 9.89 \text { vs } \\
>11.70 / 9.89\end{array}$ & $\begin{array}{l}\text { Postmenopausal: } \\
0.23(0.07-0.78)\end{array}$ & $\begin{array}{l}\text { Postmenopausal: } \\
0.018\end{array}$ \\
\hline
\end{tabular}


Table 3 Summary of observational studies on the association between ARA and risk of breast cancer (Continued)

\begin{tabular}{|c|c|c|c|c|c|c|c|c|c|}
\hline \multicolumn{10}{|c|}{ Exposure assessment: tissue ARA level } \\
\hline $\begin{array}{l}\text { Bagga et al. } \\
2002 \text { [61] }\end{array}$ & $\begin{array}{l}\text { Survey, USA, 1995- } \\
\text { 1996, case-control } \\
\text { design }\end{array}$ & $\begin{array}{l}73 \text { breast cancer } \\
\text { patients, } 73 \text { controls } \\
\text { undergoing reduction } \\
\text { mammoplasty for } \\
\text { mastomegaly, } \\
\text { matching not indicated }\end{array}$ & $\begin{array}{l}\text { Breast adipose } \\
\text { tissue fatty acids, } \\
\text { GC analysis, } \\
\text { precision not } \\
\text { indicated }\end{array}$ & Not shown & None & 15 & $\begin{array}{l}\text { ARA } \\
\text { concentration, } \\
\mu m o l / g \text { total } \\
\text { fatty acid, mean } \\
\text { (SEM) } \\
\text { Case: } \\
15.03(1.20)\end{array}$ & $\begin{array}{l}\text { ARA } \\
\text { concentration, } \\
\mu \text { mol/g total } \\
\text { fatty acid, mean } \\
\text { (SEM) } \\
\text { Control: } \\
13.13(1.25)\end{array}$ & 0.27 \\
\hline $\begin{array}{l}\text { Maillard } \\
\text { et al. } 2002 \\
\text { [62] }\end{array}$ & $\begin{array}{l}\text { Survey, France, 1992- } \\
\text { 1996, case-control } \\
\text { design }\end{array}$ & $\begin{array}{l}241 \text { patients with non- } \\
\text { metastatic invasive } \\
\text { breast carcinoma, } 88 \\
\text { controls with benign } \\
\text { breast diseases, } \\
\text { matching not indicated }\end{array}$ & $\begin{array}{l}\text { Breast adipose } \\
\text { tissue } \\
\text { triglycerides, GC } \\
\text { analysis blinded } \\
\text { to case-control } \\
\text { status, precision } \\
\text { indicated }\end{array}$ & Not shown & $\begin{array}{l}\text { Age at diagnosis, } \\
\text { height, BMI, } \\
\text { menopausal status, BMI- } \\
\text { menopausal status } \\
\text { interaction }\end{array}$ & 16 & $\begin{array}{l}\text { ARA } \\
\text { composition\%, } \\
\text { tertile } \\
\text { T1 } \\
\text { T2 } \\
\text { T3 }\end{array}$ & $\begin{array}{l}\mathrm{OR}(95 \% \mathrm{Cl}) \\
1.00 \\
0.87(0.41-1.84) \\
0.98(0.42-2.29)\end{array}$ & $\begin{array}{l}\text { Ptrend } \\
0.32\end{array}$ \\
\hline $\begin{array}{l}\text { Zhu et al. } \\
1995 \text { [58] }\end{array}$ & $\begin{array}{l}\text { Survey, Finland, 1990- } \\
1992\end{array}$ & $\begin{array}{l}26 \text { premenopausal, } 47 \\
\text { postmenopausal } \\
\text { primary breast cancer } \\
\text { patients, } 35 \\
\text { premenopausal, } 20 \\
\text { postmenopausal } \\
\text { controls with benign } \\
\text { breast disease } \\
\text { (eligibility criteria not } \\
\text { shown), matching not } \\
\text { indicated }\end{array}$ & $\begin{array}{l}\text { Breast adipose } \\
\text { tissue } \\
\text { triglycerides and } \\
\text { phospholipids, } \\
\text { GC analysis, } \\
\text { precision not } \\
\text { indicated }\end{array}$ & $\begin{array}{l}\text { Histological } \\
\text { diagnosis }\end{array}$ & Age & 13 & $\begin{array}{l}\text { Triglyceride ARA } \\
\text { composition mol } \\
\% \text {, mean(SD) } \\
\text { Premenopausal } \\
\text { case: } \\
\text { 0.33(0.18) } \\
\text { Postmenopausal } \\
\text { case: } \\
\text { 0.33(0.18) } \\
\text { Phospholipid } \\
\text { ARA } \\
\text { composition mol } \\
\text { \%, mean(SD), } \\
\text { Premenopausal } \\
\text { case: } \\
\text { 9.67(2.56) } \\
\text { Postmenopausal } \\
\text { case: } \\
\text { 9.64(2.26) }\end{array}$ & $\begin{array}{l}\text { Triglyceride ARA } \\
\text { composition mol } \\
\% \text {, mean(SD) } \\
\text { Premenopausal } \\
\text { control: } \\
\text { 0.33(0.27) } \\
\text { Postmenopausal } \\
\text { control: } \\
0.55(0.62) \\
\text { Phospholipid } \\
\text { ARA } \\
\text { composition mol } \\
\text { \%, mean(SD), } \\
\text { Premenopausal } \\
\text { control: } \\
\text { 9.58(2.17) } \\
\text { Postmenopausal } \\
\text { control: } \\
\text { 10.95(3.26) }\end{array}$ & $\begin{array}{l}\text { P } \\
\text { Triglyceride } \\
\text { Premenopausal: } \\
\text { Not significant } \\
\text { Postmenopausal: } \\
<0.01\end{array}$ \\
\hline $\begin{array}{l}\text { Petrek et al. } \\
1994 \text { [63] }\end{array}$ & $\begin{array}{l}\text { Survey, USA, 1987- } \\
\text { 1989, case-control } \\
\text { design }\end{array}$ & $\begin{array}{l}154 \text { invasive breast } \\
\text { cancer patients, } 125 \\
\text { controls at average risk } \\
\text { of breast cancer, } \\
\text { matching not indicated }\end{array}$ & $\begin{array}{l}\text { Breast adipose } \\
\text { tissue fatty acids, } \\
\text { GC analysis, } \\
\text { precision not } \\
\text { indicated }\end{array}$ & $\begin{array}{l}\text { Histological } \\
\text { diagnosis }\end{array}$ & None & 7 & $\begin{array}{l}\text { ARA } \\
\text { composition } \\
\text { weight } \% \text {, mean } \\
\text { (SD) } \\
\text { Case: } \\
0.40(0.15)\end{array}$ & $\begin{array}{l}\text { ARA } \\
\text { composition } \\
\text { weight\%, mean } \\
\text { (SD) } \\
\text { Control: } \\
0.39(0.16)\end{array}$ & Not significant \\
\hline
\end{tabular}


Table 3 Summary of observational studies on the association between ARA and risk of breast cancer (Continued)

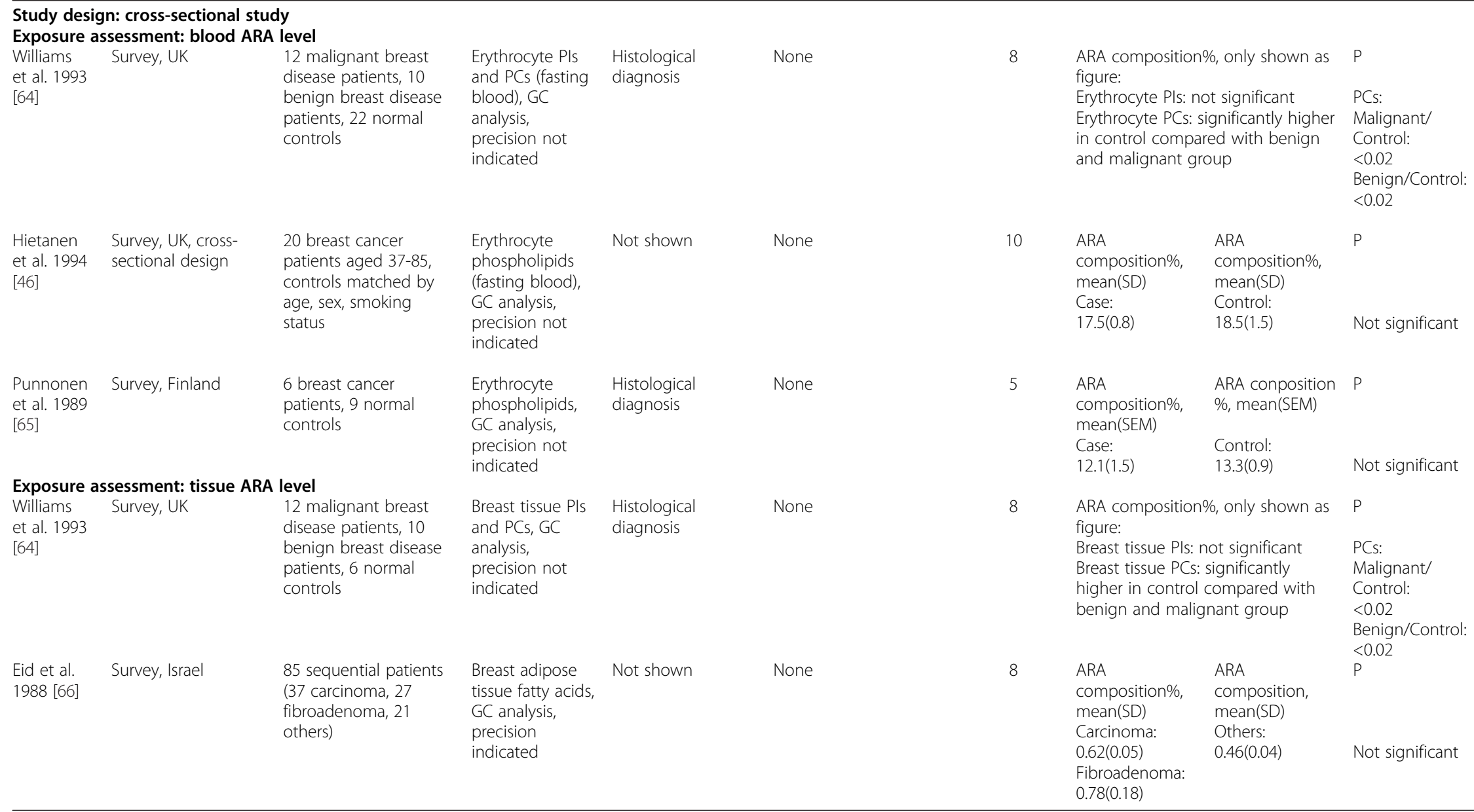

ARA Arachidonic acid, BMI Body mass index, DR Diet record, FD Food record, FFQ Food frequency questionnaire, GC Gas chromatography, HRT Hormone replacement therapy, MONICA multinational study for Monitoring of Trends and Cardiovascular Disease study, MSP Mammary-Screening Project, NHS Nurses' Health study, NLCS Netherlands Cohort Study on Diet and Cancer, NYUWHS New York University Women's Health Study, OR Odds ratio, ORDET study: the Hormones and Diet in the Etiology of Breast Cancer Risk study, PC Phosphatidyl-choline, PI Phosphatidyl-inositol, RR Relative risk, UK United Kingdom, USA United States of America, VIP Västerbotten Intervention Project, WHR Waist-to-hip ratio, WR Weighed dietary record.

*Result of the critical evaluation carried out using the STROBE tool. 
in two reports [30,31], whereas four articles $[38,40,43,46]$ indicated a negative association or significant ARA decrease with blood ARA levels, and no article reported a positive relationship between colorectal cancer risk and tissue ARA level. These inconsistent results seem to indicate that there is little firm evidence that ARA correlates with the risk of cancer.

There were limited numbers of studies on skin cancer, and they varied in the assessment method used for ARA exposure and the target cancer. It is therefore impossible to draw any conclusions from the results.

Among studies for breast and prostate cancer, a strong positive association and a clear dose-response relationship between increased cancer risk and ARA exposure were not observed, although the results were replicated in different settings using different methods. This suggests that ARA exposure is not associated with increased breast and prostate cancer risk.

We suppose that the contradictory findings mentioned above were caused by four main factors. First, methodologies for estimating dietary ARA intake have not been developed sufficiently. Most adults with mixed diets consume approximately 50 to $250 \mathrm{mg}$ of ARA per day from foodstuffs [82-84], whereas some articles on colorectal and prostate cancer have reported lower values $[30,36,39,68,74]$. Various validated questionnaires were used in articles which assessed dietary ARA intake, but the validation was not conducted for ARA specifically; total fat, saturated fatty acids, monounsaturated fatty acids, polyunsaturated fatty acids, linoleic acid, or eicosapentaenoic acid intake was assessed, but ARA was not. Since the validity of the estimation of dietary ARA intake is sometimes not enough [82], it should be considered whether exposure assessment is conducted with an appropriate method.

Second, assessment of ARA biomarkers such as blood or tissue ARA levels was diverse; assessed blood fractions included erythrocyte, serum, plasma, or total blood. Tissue sampling was conducted from adipose tissue of buttock or malignant target cancer tissue (i.e., colon, skin, breast, and prostate). Individual biomarkers of fatty acids represent intakes for different time periods [85]. Serum or plasma levels of ARA are considered to reflect dietary intake over a few days, whereas erythrocyte and tissue ARA composition serve as more long-term biomarkers. Overall, habitual dietary ARA intake could not be assessed sufficiently in articles that measured ARA composition of serum or plasma, and this might be one of the causes of inconsistent results among eligible articles.

Third, methodologies of participant selection used in the reports could lead to selection bias. A nested case-control study from a physicians' health study (aspirin and betacarotene intervention study) did not consider trial intervention through the participant selection procedure [73]. Also, reporting of participant selection was important; among the total of 52 articles, 28 did not sufficiently report the eligibility criteria, and the sources and methods of participant selection, and 31 did not fully describe the numbers of individuals at each stage of the study and reasons for nonparticipation. This makes it difficult to estimate the effect of selection bias, and therefore, the relationship between ARA intake and cancer risk could not be determined.

Fourth, publication bias based on findings of a significant association could exist, especially in breast and prostate cancers. We evaluated publication bias qualitatively, not using any statistical tests. Most of the significant results were found in the studies with low reporting quality. There is a possibility of publication bias. The results of the studies with low reporting quality may tend to be significant by chance, due to the lack of appropriate design. This suggests that publication bias may affect our review result on breast and prostate cancers, but the effect should be small, because we did not give importance to these studies with low reporting quality.

The biological plausibility of the relationship between ARA intake and cancer risk is still being debated. Previous clinical studies with aspirin or nonsteroidal antiinflammatory drugs (NSAIDs) have suggested that the cyclooxygenase metabolites of ARA may be associated with risk for colorectal, breast, and prostate cancers [21-24]. Many observational studies, however, have failed to find any association between ARA intake, or its level in blood or tissue, and cancer risk. These controversial findings may be explained by the following three reasons. First, ARA levels of blood or tissue may not always represent dietary intake. Garland et al. and Kobayashi et al. reported that correlations between dietary estimates and the ARA contents of adipose tissue or serum phospholipids were very low $[82,86]$. Second, the increment of blood or tissue ARA levels may not be connected with the amount of ARA metabolites. Our previous study, in which the supplementation of 240 or $720 \mathrm{mg}$ of ARA per day in healthy elderly persons for four weeks was conducted, investigated plasma $\mathrm{PGE}_{2}$ and urinary $\mathrm{PGE}_{2}$ metabolites [87]. Their concentrations did not differ significantly with regard to ARA supplementation or time points, although plasma ARA compositions increased dose-dependently. Third, ARA metabolites that are produced by pathways other than the cyclooxygenase pathway may decrease cancer risk. $\mathrm{LXA}_{4}$ is an anti-inflammatory mediator produced by the lipoxygenase pathway and is regarded to be a suppressor of tumour growth based on anti-angiogenic properties $[25,88]$. Aspirin or NSAIDs may not only inhibit the production of cyclooxygenase metabolites, but also divert ARA into the lipoxygenase pathway. However, it is unclear whether $\mathrm{LXA}_{4}$ contributes to reduced cancer risk in humans.

In the present study, we reviewed all bibliographies of full-text articles for potential inclusion because reference 
Table 4 Summary of observational studies on the association between ARA and risk of prostate cancer

\begin{tabular}{|c|c|c|c|c|c|c|c|c|c|}
\hline \multirow[t]{2}{*}{ References } & \multirow[t]{2}{*}{ Study } & \multirow[t]{2}{*}{ Subjects } & \multirow{2}{*}{$\begin{array}{l}\text { Exposure } \\
\text { Assessment }\end{array}$} & \multirow{2}{*}{$\begin{array}{l}\text { Prostate cancer } \\
\text { assessment } \\
\text { (diagnosis) }\end{array}$} & \multirow{2}{*}{$\begin{array}{l}\text { Adjustment for potential } \\
\text { confounders }\end{array}$} & \multirow{2}{*}{$\begin{array}{l}\text { Assessment } \\
\text { of reporting } \\
\text { quality * }\end{array}$} & \multicolumn{3}{|c|}{ Main findings } \\
\hline & & & & & & & Intergroup & comparison & $\begin{array}{l}\mathrm{P} \text { or } \\
\text { Ptrend }\end{array}$ \\
\hline \multicolumn{10}{|c|}{$\begin{array}{l}\text { Study design: cohort study } \\
\text { Exposure assessment: dietary intake }\end{array}$} \\
\hline $\begin{array}{l}\text { Leitzmann } \\
\text { et al. } 2004 \\
\text { [67] }\end{array}$ & $\begin{array}{l}\text { HPFS, USA, 1986-2000, } \\
\text { prospective cohort } \\
\text { design ( } 14 \text { years follow- } \\
\text { up) }\end{array}$ & $\begin{array}{l}47,866 \text { health professionals } \\
\text { aged } 40-65, \text { no prior history } \\
\text { of cancer }\end{array}$ & $\begin{array}{l}\text { Semiquantitative } \\
\text { FFQ, } 131 \text { items, } \\
\text { validated against } \\
2 \times 1 \text {-week DR }\end{array}$ & $\begin{array}{l}\text { Self-reported } \\
\text { physician diagnosis } \\
\text { supplemented by } \\
\text { medical record } \\
\text { and pathology } \\
\text { report }\end{array}$ & $\begin{array}{l}\text { Age, time period, race, } \\
\text { family history of prostate } \\
\text { cancer, history of type } 2 \text { DM } \\
\text { and vasectomy, BMI, height, } \\
\text { smoking status, physical } \\
\text { activity, total energy intake, } \\
\% \text { of energy from protein } \\
\text { intake, monounsaturated fat } \\
\text { intake, saturated fat intake } \\
\text { and trans unsaturated fat } \\
\text { intake, calcium intake, } \\
\text { supplemental vitamin E and } \\
\text { lycopene }\end{array}$ & 21 & $\begin{array}{l}\text { Dietary ARA } \\
\text { intake, } \% \\
\text { energy, } \\
\text { quintile } \\
\text { Q1: }<0.028 \\
\text { Q2: } 0.028- \\
0.035 \\
\text { Q3: } 0.036- \\
0.041 \\
\text { Q4: } 0.042- \\
0.049 \\
\text { Q5: }>0.049\end{array}$ & $\begin{array}{l}1.00 \\
1.06(0.94- \\
1.19) \\
1.04(0.92- \\
1.18) \\
1.02(0.89- \\
1.16) \\
1.08(0.94- \\
1.25)\end{array}$ & Ptrend \\
\hline \multicolumn{10}{|c|}{$\begin{array}{l}\text { Study design: nested case-control study } \\
\text { Exposure assessment: dietary intake }\end{array}$} \\
\hline $\begin{array}{l}\text { Männistö } \\
\text { et al. } 2003 \\
\text { [68] }\end{array}$ & $\begin{array}{l}\text { ATBC study, Finland, } \\
\text { 1985-1993, nested case- } \\
\text { control design (5-8 } \\
\text { years follow-up) }\end{array}$ & $\begin{array}{l}198 \text { prostate cancer patients, } \\
198 \text { controls (free of prostate } \\
\text { cancer) matched by age, trial } \\
\text { supplementation group }\end{array}$ & $\begin{array}{l}\text { Self-administered } \\
\text { dietary } \\
\text { questionnaire, } \\
276 \text { items, } \\
\text { validated against } \\
12 \times 2 \text {-day DR }\end{array}$ & $\begin{array}{l}\text { Finnish Cancer } \\
\text { Registry and } \\
\text { Register of Causes } \\
\text { of Death }\end{array}$ & $\begin{array}{l}\text { Resident area, educational } \\
\text { level, BMI, alcohol intake, } \\
\text { smoking period }\end{array}$ & 23 & $\begin{array}{l}\text { Dietary ARA } \\
\text { intake, g/day, } \\
\text { median } \\
\text { Q1: } 0.04 \\
\text { Q2: } 0.06 \\
\text { Q3: } 0.07 \\
\text { Q4: } 0.10\end{array}$ & $\begin{array}{l}\mathrm{OR}(95 \% \mathrm{Cl}) \\
\\
1.00 \\
0.89(0.52- \\
1.54) \\
1.10(0.64- \\
1.90) \\
1.31(0.77- \\
2.21)\end{array}$ & $\begin{array}{l}\text { Ptrend } \\
0.23\end{array}$ \\
\hline $\begin{array}{l}\text { Schuurman } \\
\text { et al. } 1999 \\
\text { [69] }\end{array}$ & $\begin{array}{l}\text { NLCS, Netherlands, } \\
\text { 1986-1992 (6.3 years } \\
\text { follow-up), case-cohort } \\
\text { design }\end{array}$ & $\begin{array}{l}642 \text { primary prostate cancer } \\
\text { patients from entire cohort, } \\
1,525 \text { subcohort members } \\
\text { (selection criteria not shown) } \\
\text { aged } 55-69 \text { at baseline, } \\
\text { without prevalent cancer } \\
\text { other than skin cancer, } \\
\text { matching not indicated }\end{array}$ & $\begin{array}{l}\text { Semiquantitative } \\
\text { FFQ, } 150 \text { items, } \\
\text { validated against } \\
3 \times 3 \text {-day DR }\end{array}$ & $\begin{array}{l}\text { All regional cancer } \\
\text { registries and } \\
\text { Dutch national } \\
\text { database of } \\
\text { pathology reports }\end{array}$ & $\begin{array}{l}\text { Age, family history of } \\
\text { prostate carcinoma, } \\
\text { socioeconomic status, total } \\
\text { energy intake, total energy- } \\
\text { adjusted fat intake }\end{array}$ & 23 & $\begin{array}{l}\text { Dietary ARA } \\
\text { intake, g/day, } \\
\text { quintile, } \\
\text { median } \\
\text { Q1: } 0.06 \\
\text { Q2: } 0.09 \\
\text { Q3: } 0.11 \\
\text { Q4: } 0.13 \\
\text { Q5: } 0.17\end{array}$ & $\begin{array}{l}1.00 \\
1.21(0.88- \\
1.66) \\
1.37(1.00- \\
1.87) \\
1.11(0.80- \\
1.54) \\
1.20(0.87- \\
1.66)\end{array}$ & Ptrend \\
\hline
\end{tabular}


Table 4 Summary of observational studies on the association between ARA and risk of prostate cancer (Continued)

\begin{tabular}{|c|c|c|c|c|c|c|c|c|c|}
\hline \multicolumn{10}{|c|}{ Exposure assessment: blood ARA level } \\
\hline $\begin{array}{l}\text { Crowe et al. } \\
2008 \text { [70] }\end{array}$ & $\begin{array}{l}\text { EPIC study, Denmark, } \\
\text { Germany, Greece, Italy, } \\
\text { Netherlands, Spain, } \\
\text { Sweden, UK, 1992-2000, } \\
\text { nested case-cohort } \\
\text { design }\end{array}$ & $\begin{array}{l}962 \text { prostate cancer patients, } \\
1,061 \text { controls without } \\
\text { prevalent cancer other than } \\
\text { NMSC, } 1 \text { case matched with } \\
1-2 \text { control(s) by study } \\
\text { center, age, time of blood } \\
\text { sampling, time between } \\
\text { blood sampling and last } \\
\text { consumption of food or } \\
\text { drink }\end{array}$ & $\begin{array}{l}\text { Plasma } \\
\text { phospholipids, } \\
\text { GC analysis, } \\
\text { precision } \\
\text { indicated }\end{array}$ & $\begin{array}{l}\text { Regional or } \\
\text { national cancer } \\
\text { registries or } \\
\text { combination of } \\
\text { health insurance } \\
\text { records, cancer } \\
\text { and pathology } \\
\text { registries and self- } \\
\text { report }\end{array}$ & $\begin{array}{l}\text { BMI, smoking status, alcohol } \\
\text { intake, educational level, } \\
\text { marital status, physical } \\
\text { activity }\end{array}$ & 26 & $\begin{array}{l}\text { ARA } \\
\text { composition } \\
\text { mol\%, quintile } \\
\text { Q1: 4.40-7.93 } \\
\text { Q2: 7.93-8.89 } \\
\text { Q3: 8.90-9.86 } \\
\text { Q4: 9.86-10.98 } \\
\text { Q5: 10.99- } \\
\text { 19.14 }\end{array}$ & $\begin{array}{l}\text { RR(95\%Cl) } \\
\\
1.00 \\
1.28(0.96- \\
1.70) \\
1.17(0.88- \\
1.56) \\
0.81(0.60- \\
1.10) \\
0.91(0.65- \\
1.25)\end{array}$ & $\begin{array}{l}\text { Ptrend } \\
0.419\end{array}$ \\
\hline $\begin{array}{l}\text { Chavarro } \\
\text { et al. } 2007 \\
\text { [71] }\end{array}$ & $\begin{array}{l}\text { PHS, USA, 1982-1995, } \\
\text { nested case-control } \\
\text { design within a } \\
\text { randomized, double- } \\
\text { blind, placebo- } \\
\text { controlled factorial } \\
\text { aspirin and beta- } \\
\text { carotene trial (13 years } \\
\text { follow-up) }\end{array}$ & $\begin{array}{l}476 \text { prostate cancer patients, } \\
476 \text { controls, male physicians } \\
\text { without history of cancer } \\
\text { except NMSC, } 1 \text { case } \\
\text { matched with } 1 \text { control by } \\
\text { age, smoking status, with } \\
\text { consideration for trial } \\
\text { intervention }\end{array}$ & $\begin{array}{l}\text { Whole blood } \\
\text { fatty acids, GC } \\
\text { analysis blinded } \\
\text { to case-control } \\
\text { status, precision } \\
\text { indicated }\end{array}$ & $\begin{array}{l}\text { Self-report, } \\
\text { combined with } \\
\text { review of hospital } \\
\text { records and } \\
\text { pathology reports }\end{array}$ & $\begin{array}{l}\text { Age, smoking status, length } \\
\text { of follow-up }\end{array}$ & 22 & $\begin{array}{l}\text { ARA } \\
\text { concentration } \\
(\%) \text {, quintile, } \\
\text { median } \\
\text { Q1: } 7.9 \\
\text { Q2: } 9.3 \\
\text { Q3: } 10.1 \\
\text { Q4: } 10.9 \\
\text { Q5: } 12.3\end{array}$ & $\begin{array}{l}1.00 \\
1.22(0.82- \\
1.81) \\
1.05(0.70- \\
1.57) \\
0.98(0.66- \\
1.46) \\
1.09(0.72- \\
1.64)\end{array}$ & $\begin{array}{l}\text { Ptrend } \\
0.98\end{array}$ \\
\hline $\begin{array}{l}\text { Männistö } \\
\text { et al. } 2003 \\
\text { [68] }\end{array}$ & $\begin{array}{l}\text { ATBC study, Finland, } \\
\text { 1985-1993, nested case- } \\
\text { control design (5-8 } \\
\text { years follow-up) }\end{array}$ & $\begin{array}{l}198 \text { prostate cancer patients, } \\
198 \text { controls (free of prostate } \\
\text { cancer) matched by age, trial } \\
\text { supplementation group }\end{array}$ & $\begin{array}{l}\text { Serum } \\
\text { cholesterol ester } \\
\text { fatty acids, GC } \\
\text { analysis, } \\
\text { precision } \\
\text { indicated }\end{array}$ & $\begin{array}{l}\text { Finnish Cancer } \\
\text { Registry and } \\
\text { Register of Causes } \\
\text { of Death }\end{array}$ & $\begin{array}{l}\text { Resident area, educational } \\
\text { level, BMl, alcohol intake, } \\
\text { smoking period }\end{array}$ & 23 & $\begin{array}{l}\text { ARA } \\
\text { composition } \\
\text { \%, quartile, } \\
\text { median } \\
\text { Q1: } 3.96 \\
\text { Q2: } 4.55 \\
\text { Q3: } 5.09 \\
\text { Q4: } 5.89\end{array}$ & $\begin{array}{l}1.00 \\
1.05(0.60- \\
1.84) \\
0.94(0.54- \\
1.64) \\
1.39(0.79- \\
2.44)\end{array}$ & Ptrend \\
\hline $\begin{array}{l}\text { Harvei et al. } \\
1997[72]\end{array}$ & $\begin{array}{l}\text { Janus serum bank, } \\
\text { Norway, 1973-1994, } \\
\text { nested case-control } \\
\text { design }\end{array}$ & $\begin{array}{l}141 \text { prostate cancer patients, } \\
282 \text { controls (eligibility } \\
\text { criteria not shown), } 1 \text { case } \\
\text { matched with } 2 \text { controls by } \\
\text { age, date of blood sampling, } \\
\text { resident area }\end{array}$ & $\begin{array}{l}\text { Serum } \\
\text { phospholipids, } \\
\text { GC analysis, } \\
\text { blinded to case- } \\
\text { control status, } \\
\text { precision not } \\
\text { indicated }\end{array}$ & $\begin{array}{l}\text { Cancer Registry } \\
\text { and Statistics } \\
\text { Norway }\end{array}$ & None & 14 & $\begin{array}{l}\text { ARA } \\
\text { concentration } \\
\text { mg/l, quartile, } \\
\text { upper limit } \\
\text { Q1: } 4.86 \\
\text { Q2: } 5.68 \\
\text { Q3: } 6.68 \\
\text { Q4: }>6.68\end{array}$ & $\begin{array}{l}1.0 \\
1.1(0.6-1.9) \\
1.2(0.7-2.1) \\
0.8(0.4-1.5)\end{array}$ & Ptrend \\
\hline
\end{tabular}


Table 4 Summary of observational studies on the association between ARA and risk of prostate cancer (Continued)

\begin{tabular}{lllll}
\hline Gann et al. & PHS, USA, 1982-1988, & 120 prostate cancer patients, & Plasma & Self-report, \\
1994 [73] & nested case-control & 120 controls, male physicians & cholesterol ester & combined with \\
& design within a & without history of cancer & fatty acids, GC & review of medical \\
randomized, double- & except NMSC, 1 case & analysis blinded & records \\
blind, placebo- & matched with 1 control by & to case-control & \\
controlled factorial & age, smoking status without & status, precision & \\
$\begin{array}{l}\text { aspirin and beta- } \\
\text { carotene trial (6 years }\end{array}$ & regard to trial intervention & indicated & \\
follow-up) & & & \\
& & &
\end{tabular}

None

19

ARA

$\mathrm{OR}$

Ptrend

composition

clasma

estel \%,

quartile

Q1 2

$\begin{array}{ll}\text { Q3 } & 1.00 \\ \text { Q4 } & 1.36(v) \text { Q1 }\end{array}$

1.00

1.81

$95 \% \mathrm{Cl}:$

$0.63-2.90$

Study design: case-control study (temporal relationship among exposure and outcome is unclear)

Exposure assessment: dietary intake

Hodge Survey, Australia, 1994- 858 prostate cancer patients Melbourne FFQ, Not shown

et al. 2004 1997, case-control aged <70, 905 controls

121 items,

$[74]$

design

matched by age

validated against

Age at selection, study

center, calendar year, family

history of prostate cancer,

country of birth,

socioeconomic status

quintile

Q1: $<0.028 \quad 1.0$

Q2: 0.028- $1.2(0.8-1.6)$

0.036

Q3: 0.037-

0.046

Q4: 0.047

0.059

$1.2(0.8-1.6)$

Q5: $\geq 0.06$

$1.0(0.7-1.3)$

1.0(0.7-1.4)

Exposure assessment: blood ARA level

Ukori et al. Survey, USA and Nigeria, 48 African American and 66

2010 [75] Nigerian prostate cancer

Plasma fatty and 226 Nigerian controls, acids (fastin blood), GC

Abnormal DRE aged $\geq 40$, without any

analysis,

Age, educational level,

cancer history other than

precision not

with histological

family history of prostate

cancer, WHR

ARA

OR(95\%Cl) Ptrend

concentration

$\mu \mathrm{g} / \mathrm{ml}$,

quartile

American

African:

indicated

Q1 vs Q4

Nigerian:

Q1 vs Q4

African: African:

0.3(0.08-1.11) <0.05

Nigerian: Nigerian:

0.75(0.32- Not

1.74) significant 
Table 4 Summary of observational studies on the association between ARA and risk of prostate cancer (Continued)

\begin{tabular}{|c|c|c|c|c|c|c|c|c|c|}
\hline $\begin{array}{l}\text { Ukori et al. } \\
2009 \text { [76] }\end{array}$ & $\begin{array}{l}\text { Survey, Nigeria, case- } \\
\text { control design }\end{array}$ & $\begin{array}{l}66 \text { prostate cancer patients, } \\
226 \text { controls, aged } \geq 40, \\
\text { matching not indicated } \\
\text { (same population as Nigerian } \\
\text { participants of Ukori et al. } \\
2010 \text { ) }\end{array}$ & $\begin{array}{l}\text { Plasma fatty } \\
\text { acids (fasting } \\
\text { blood), GC } \\
\text { analysis, } \\
\text { precision not } \\
\text { indicated }\end{array}$ & $\begin{array}{l}\text { Abnormal DRE } \\
\text { and/or abnormal } \\
\text { PSA ( }>4 \mathrm{ng} / \mathrm{ml}) \\
\text { with histological } \\
\text { diagnosis }\end{array}$ & $\begin{array}{l}\text { Age, educational level, } \\
\text { family history of prostate } \\
\text { cancer, WHR }\end{array}$ & 11 & $\begin{array}{l}\text { ARA } \\
\text { concentration } \\
\mu \mathrm{g} / \mathrm{ml} \text {, } \\
\text { quartile } \\
\text { Q1 } \\
\text { Q2 } \\
\text { Q3 } \\
\text { Q4 }\end{array}$ & $\begin{array}{l}1.00 \\
2.59(0.85- \\
7.86) \\
1.93(0.73- \\
5.14) \\
0.75(0.32- \\
1.74)\end{array}$ & Ptrend \\
\hline $\begin{array}{l}\text { Newcomer } \\
\text { et al. } 2001 \\
\text { [77] }\end{array}$ & $\begin{array}{l}\text { Survey, USA, case- } \\
\text { control design }\end{array}$ & $\begin{array}{l}67 \text { prostate cancer patients, } \\
156 \text { population-based } \\
\text { controls, } 1 \text { case matched } \\
\text { with about } 2 \text { controls by age } \\
\text { distribution }\end{array}$ & $\begin{array}{l}\text { Erythrocyte fatty } \\
\text { acids, GC analysis } \\
\text { blinded to case- } \\
\text { control status, } \\
\text { precision } \\
\text { indicated }\end{array}$ & Not shown & Age & 23 & $\begin{array}{l}\text { ARA } \\
\text { composition } \\
\text { weight } \% \text {, } \\
\text { quartile } \\
\text { Q1: } \leq 13.25 \\
\text { Q2: 13.26- } \\
\text { 14.12 } \\
\text { Q3: } 14.13- \\
\text { 14.90 } \\
\text { Q4: } \geq 14.91\end{array}$ & $\begin{array}{l}1.0 \\
1.6(0.7-3.7) \\
1.6(0.7-3.5) \\
0.9(0.4-2.3)\end{array}$ & $\begin{array}{l}\text { Ptrend } \\
0.88\end{array}$ \\
\hline $\begin{array}{l}\text { Yang et al. } \\
1999[78]\end{array}$ & Survey, Korea & $\begin{array}{l}19 \text { prostate cancer patients, } \\
24 \text { benign prostatic } \\
\text { hyperplasia patients, } 21 \\
\text { normal controls, matched by } \\
\text { age, demographics }\end{array}$ & $\begin{array}{l}\text { Serum fatty } \\
\text { acids, GC-MS } \\
\text { analysis, } \\
\text { precision not } \\
\text { indicated }\end{array}$ & Not shown & None & 4 & $\begin{array}{l}\text { ARA } \\
\text { composition } \\
\% \text {, mean (SD) } \\
\text { Cancer: } \\
\text { 0.77(0.31) } \\
\text { Benign: } \\
0.95(0.16)\end{array}$ & $\begin{array}{l}\text { ARA } \\
\text { composition } \\
\% \text {, mean } \\
\text { (SD) } \\
\text { Normal } \\
\text { control: } \\
1.15(0.45)\end{array}$ & $\begin{array}{l}\text { Not } \\
\text { significant }\end{array}$ \\
\hline \multicolumn{10}{|c|}{$\begin{array}{l}\text { Study design: cross-sectional study } \\
\text { Exposure assessment: blood ARA level }\end{array}$} \\
\hline $\begin{array}{l}\text { Faas et al. } \\
2003 \text { [79] }\end{array}$ & Survey, USA, 1995-1998 & $\begin{array}{l}\text { Prostate cancer patients, } \\
\text { benign prostate disease } \\
\text { patients }\end{array}$ & $\begin{array}{l}\text { Erythrocyte and } \\
\text { plasma } \\
\text { phospholipids, } \\
\text { GC analysis, } \\
\text { precision not } \\
\text { indicated }\end{array}$ & Pathology reports & None & 10 & $\begin{array}{l}\text { Erythrocyte } \\
\text { ARA } \\
\text { composition } \\
\% \text {, mean(SEM) } \\
\text { Malignant: } \\
\text { 16.33(0.28) } \\
\text { Plasma ARA } \\
\text { composition } \\
\% \text {, mean(SEM) } \\
\text { Malignant: } \\
\text { 12.60(0.27) }\end{array}$ & $\begin{array}{l}\text { Erythrocyte } \\
\text { ARA } \\
\text { composition } \\
\% \text {, mean } \\
\text { (SEM) } \\
\text { Benign: } \\
16.68(0.25) \\
\\
\text { Plasma ARA } \\
\text { composition } \\
\% \text {, mean } \\
\text { (SEM) } \\
\text { Benign: } \\
\text { 13.03(0.29) }\end{array}$ & $\begin{array}{l}\text { Erythrocyte: } \\
\text { Not } \\
\text { significant }\end{array}$ \\
\hline
\end{tabular}


Table 4 Summary of observational studies on the association between ARA and risk of prostate cancer (Continued)

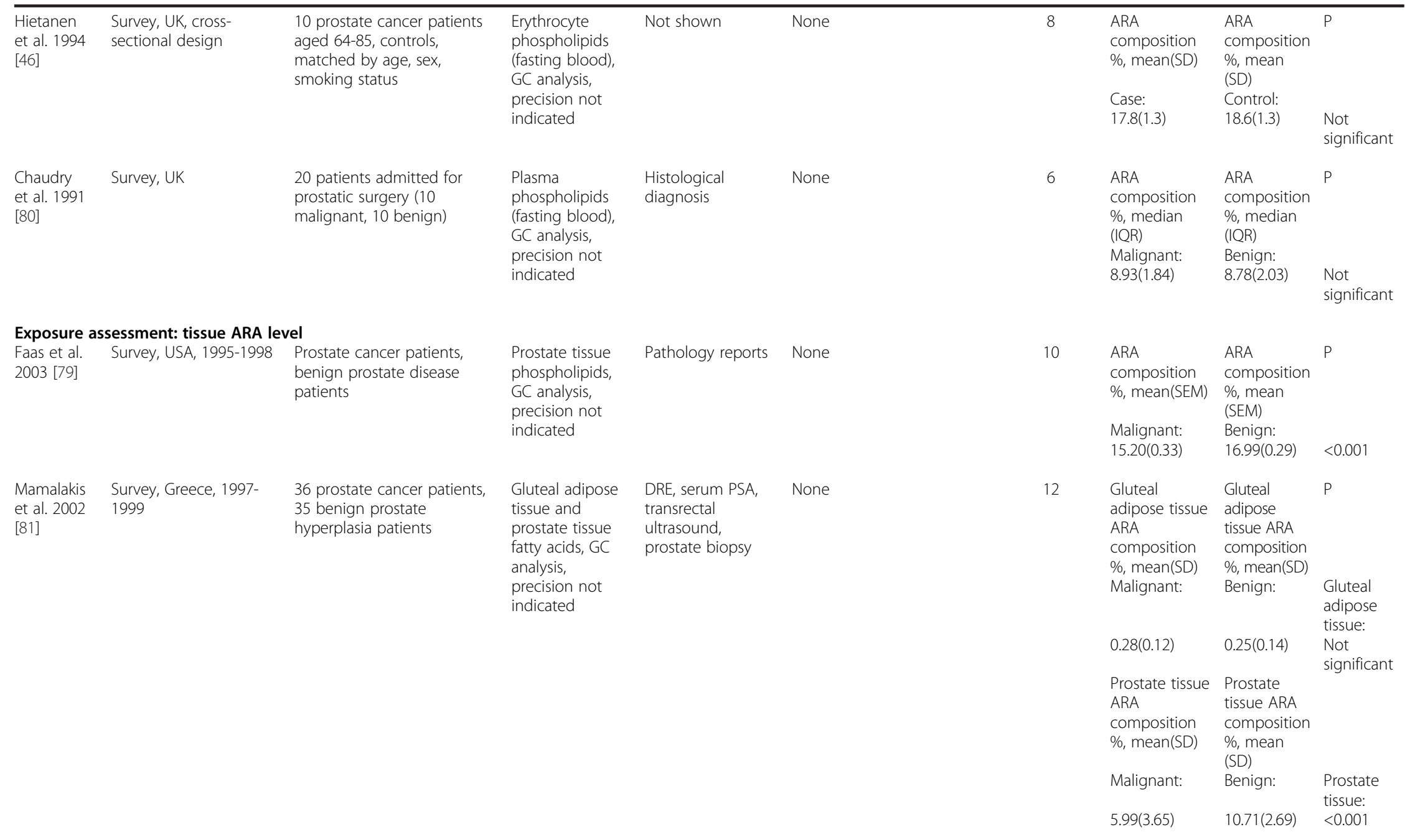


Table 4 Summary of observational studies on the association between ARA and risk of prostate cancer (Continued)

\begin{tabular}{|c|c|c|c|c|c|c|c|c|c|}
\hline $\begin{array}{l}\text { Chaudry } \\
\text { et al. } 1991 \\
\text { [80] }\end{array}$ & Survey, UK & $\begin{array}{l}20 \text { patients admitted for } \\
\text { prostatic surgery ( } 10 \\
\text { malignant, } 10 \text { benign) }\end{array}$ & $\begin{array}{l}\text { Prostate tissue } \\
\text { phospholipids, } \\
\text { GC analysis, } \\
\text { precision not } \\
\text { indicated }\end{array}$ & $\begin{array}{l}\text { Histological } \\
\text { diagnosis }\end{array}$ & None & 6 & $\begin{array}{l}\text { ARA } \\
\text { composition } \\
\% \text {, median } \\
\text { (IQR) } \\
\text { Malignant: } \\
11.33(4.12)\end{array}$ & $\begin{array}{l}\text { ARA } \\
\text { composition } \\
\% \text {, median } \\
\text { (IQR) } \\
\text { Benign: } \\
15.55(2.54)\end{array}$ & 0.002 \\
\hline
\end{tabular}

ARA Arachidonic acid, ATBC Study: Alpha-tocopherol. Beta-carotene cancer prevention study, BMI Body mass index, DM Diabetes mellitus, DR Diet record, DRE Digital rectal examination, EPIC European prospective investigation into cancer and nutrition, FFQ Food frequency questionnaire, GC Gas chromatography, HPFS Health professionals follow-up study, IQR Interquartile range, NLCS Netherlands cohort study on diet and cancer, NMSC Non-melanoma skin cancer, OR Odds ratio, PHS Physician's health study, PSA Serum level of prostate specific antigen, RR Relative risk, UK United Kingdom, USA United States of America, USDA United states Department of Agriculture, WFR Weighed food record, WHR Waist-to-hip ratio.

* Result of the critical evaluation carried out using the STROBE tool. 
searches serve an important role in comprehensive literature searches. 49,670 articles were listed, and 99.9\% of them were not eligible. We considered that this large exclusion resulted from the many articles in which ARA was not described at all; therefore, we tried another reference search from the bibliographies of articles after their exclusion. Fifty full-text articles from the PubMed database and 146 from the reference search mentioned ARA. A total of 13,657 articles were listed in their bibliographies and their number was reduced to a third; however, we could select 30 eligible articles out of 31 articles that were selected from all full-text searching. The one article remaining that was not selected was a report on skin cancer [50]. This might have resulted from the smaller number of articles identified on PubMed for skin cancer (10 reports) than for colorectal, breast, or prostate cancers $(48,31$, or 41 reports). This suggests that reference searches from bibliographies of articles including ARA are more efficient when enough articles are identified from the PubMed database.

This systematic review has limitations. First, studies for inclusion could not be selected independently by two or more reviewers. Our inclusion/exclusion criteria were clear and there were few differences which depended on who was in charge; however that may have introduced a potential selection bias. Second, our search was restricted to English publications and articles from the PubMed database. Furthermore, articles that investigated tissue levels of ARA as an exposure assessment could not be identified comprehensively. We did not set the search terms for ARA levels of tissue before the PubMed search, and identified the articles in the reference search. Third, the search term "fatty" or "fatty acid" was not used in the PubMed search. It led to the efficient search but may cause the possibility that the review may not be completed. Fourth, quality assessment of observational studies is difficult because of the heterogeneity of study designs and methods. The reporting quality was quantitatively expressible using the STROBE checklist; in contrast, the methodological quality could not be quantified and was qualitatively estimated by two independent reviewers. This may have seriously influenced the results and conclusions of the present review.

Note that there are insufficient studies to draw any firm conclusions about the relationship between ARA and cancer risk. Further evidence from well-designed observational studies is required.

\section{Conclusions}

In conclusion, we systematically identified articles that investigated the association between dietary ARA intake or its biomarkers and the risk of colorectal, skin, breast, prostate, lung, or stomach cancer, and only a limited number of observational studies were found $(17,3,18$, 16 , 0 , and 0 studies were found on colorectal, skin, breast, prostate, lung, or stomach cancer, respectively). Furthermore, most studies had one or more critical limitations, such as the obscurity of temporal information about exposure and outcome, the methodology of ARA exposure assessment, and inadequate treatment of potential confounding factors. These studies did not sufficiently demonstrate any relationships between ARA exposure and cancer risk; however, they seem to suggest that ARA exposure was not related to increased breast or prostate cancer risk because strong positive associations and clear dose-response relationships were not observed. Findings concerning the association between ARA exposure and colorectal cancer were inconsistent between studies. Thus, further evidence from well-designed observational studies is required to confirm or refute the association between ARA exposure and cancer risk.

\section{Additional file}

Additional file 1: PubMed search terms and strategies.

\section{Competing interests}

This study was supported in part by a grant from Suntory Wellness Limited, Japan. MS, SK, CH, HS, HK, and HS are employees of Suntory Wellness Limited. HO has no competing interests. SS has consultancy relationships with Suntory Wellness Limited.

\section{Authors' contributions}

SK conducted database searches. SK, CH, and HT made decisions on the inclusion and exclusion of the articles. MS and SK conducted quality and bias assessments, contributed to interpretation of findings, wrote the manuscript, and incorporated changes suggested by others. $\mathrm{HK}, \mathrm{HS}, \mathrm{HO}$, and SS helped to interpret the findings and refined the manuscript. All authors have read and approved the final manuscript

\section{Author details}

'Department of Social and Preventive Epidemiology, School of Public Health, The University of Tokyo, Tokyo, Japan. ${ }^{2}$ Quality Assurance Department, Suntory Wellness Limited, Tokyo, Japan. ${ }^{3}$ Institute for Health Care Science, Suntory Wellness Limited, Osaka, Japan.

Received: 17 April 2012 Accepted: 27 November 2012 Published: 19 December 2012

\section{References}

1. World Health Organization: The global burden of disease: 2004 update. Geneva: WHO; 2008.

2. International Agency for Research on Cancer: World Cancer Report 2008. Lyon: WHO; 2008.

3. Prentice RL, Caan B, Chlebowski RT, Patterson R, Kuller LH, Ockene JK, Margolis KL, Limacher MC, Manson JE, Parker LM, Paskett E, Phillips L, Robbins J, Rossouw JE, Sarto GE, Shikany JM, Stefanick ML, Thomson CA, Van Horn L, Vitolins MZ, Wactawski-Wende J, Wallace RB, WassertheilSmoller S, Whitlock E, Yano K, Adams-Campbell L, Anderson GL, Assaf AR, Beresford SA, Black HR, Brunner RL, Brzyski RG, Ford L, Gass M, Hays J, Heber D, Heiss G, Hendrix SL, Hsia J, Hubbell FA, Jackson RD, Johnson KC, Kotchen JM, LaCroix AZ, Lane DS, Langer RD, Lasser NL, Henderson MM: Low-fat dietary pattern and risk of invasive breast cancer: the Women's Health Initiative Randomized Controlled Dietary Modification Trial. JAMA 2006, 295:629-642.

4. Prentice RL, Anderson GL: The women's health initiative: lessons learned. Annu Rev Publ Health 2008, 29:131-150.

5. International Agency for Research on Cancer: Cancer: causes, occurrence and control. Lyon: John Wiley \& Sons, Ltd; 1990. 
6. Park SY, Murphy SP, Wilkens LR, Henderson BE, Kolonel LN: Fat and meat intake and prostate cancer risk: the multiethnic cohort study. Int J Cancer 2007, 121:1339-1345.

7. Beresford SA, Johnson KC, Ritenbaugh C, Lasser NL, Snetselaar LG, Black HR, Anderson GL, Assaf AR, Bassford T, Bowen D, Brunner RL, Brzyski RG, Caan B, Chlebowski RT, Gass M, Harrigan RC, Hays J, Heber D, Heiss G, Hendrix SL, Howard BV, Hsia J, Hubbell FA, Jackson RD, Kotchen JM, Kuller LH, LaCroix AZ, Lane DS, Langer RD, Lewis CE, Manson JE, Margolis KL, Mossavar-Rahmani Y, Ockene JK, Parker LM, Perri MG, Phillips L, Prentice RL, Robbins J, Rossouw JE, Sarto GE, Stefanick ML, Van Horn L, Vitolins MZ, Wactawski-Wende J, Wallace RB, Whitlock E: Low-fat dietary pattern and risk of colorectal cancer: the Women's Health Initiative Randomized Controlled Dietary Modification Trial. JAMA 2006, 295:643-654.

8. Giovannucci E, Rimm EB, Stampfer MJ, Colditz GA, Ascherio A, Willett WC: Intake of fat, meat, and fiber in relation to risk of colon cancer in men. Cancer Res 1994, 54:2390-2397.

9. Jaax S, Scott LW, Wolf JE Jr, Thornby Jl, Black HS: General guidelines for a low-fat diet effective in the management and prevention of nonmelanoma skin cancer. Nutr Canc 1997, 27:150-156.

10. Black HS, Thornby Jl, Wolf JE Jr, Goldberg LH, Herd JA, Rosen T, Bruce S, Tschen JA, Scott LW, Jaax S, Foreyt JP, Reusser B: Evidence that a low-fat diet reduces the occurrence of non-melanoma skin cancer. Int J Cancer 1995, 62:165-169.

11. Davies TW, Treasure FP, Welch AA, Day NE: Diet and basal cell skin cancer: results from the EPIC-Norfolk cohort. Br J Dermatol 2002, 146:1017-1022.

12. Mackie BS, Johnson AR, Mackie LE, Fogerty AC, Ferris M, Baxter Rl: Dietary polyunsaturated fats and malignant melanoma. Med J Aust 1980, 1:159-163.

13. James MJ, Gibson RA, Cleland LG: Dietary polyunsaturated fatty acids and inflammatory mediator production. Am J Clin Nutr 2000 71(Suppl 1):343S-3485

14. Calder PC: Polyunsaturated fatty acids, inflammation, and immunity. Lipids 2001, 36:1007-1024.

15. Benatti P, Peluso G, Nicolai R, Calvani M: Polyunsaturated fatty acids: biochemical, nutritional and epigenetic properties. J Am Coll Nutr 2004, 23:281-302

16. Dyerberg J, Bang HO, Stoffersen E, Moncada S, Vane JR: Eicosapentaenoic acid and prevention of thrombosis and atherosclerosis? Lancet 1978, 2:117-119.

17. Funk CD: Prostaglandins and leukotrienes: advances in eicosanoid biology. Science 2001, 294:1871-1875.

18. Helliwell RJA, Adams LF, Mitchell MD: Prostaglandin synthase: recent developments and a novel hypothesis. Prostag Leukot Essent Fatty Acids 2004, 70:101-113.

19. Lewis RA, Austen KF, Soberman RJ: Leukotrienes and other products of the 5-lipoxygenase pathway. Biochemistry and relation to pathobiology in human diseases. N Engl J Med 1990, 323:645-655.

20. Kuliczkowski W, Witkowski A, Polonski L, Watala C, Filipiak K, Budaj A Golanski J, Sitkiewicz D, Pregowski J, Gorski J, Zembala M, Opolski G, Huber K, Arnesen H, Kristensen SD, De Caterina R: Interindividual variability in the response to oral antiplatelet drugs: a position paper of the Working Group on antiplatelet drugs resistance appointed by the Section of Cardiovascular Interventions of the Polish Cardiac Society, endorsed by the Working Group on Thrombosis of the European Society of Cardiology. Eur Heart J 2009, 30:426-435.

21. Rostom A, Dubé C, Lewin G, Tsertsvadze A, Barrowman N, Code C, Sampson M, Moher D, US Preventive Services Task Force: Nonsteroidal anti-inflammatory drugs and cyclooxygenase-2 inhibitors for primary prevention of colorectal cancer: a systematic review prepared for the U.S. Preventive Services Task Force. Ann Intern Med 2007, 146:376-389.

22. Dubé C, Rostom A, Lewin G, Tsertsvadze A, Barrowman N, Code C, Sampson M, Moher D, US Preventive Services Task Force: The use of aspirin for primary prevention of colorectal cancer: a systematic review prepared for the U.S. Preventive Services Task Force. Ann Intern Med 2007, 146:365-375.

23. Takkouche B, Regueira-Méndez C, Etminan M: Breast cancer and use of nonsteroidal anti-inflammatory drugs: a meta-analysis. J Natl Canc Inst 2008, 100:1439-1447

24. Mahmud S, Franco E, Aprikian A: Prostate cancer and use of nonsteroidal anti-inflammatory drugs: systematic review and meta-analysis. $\mathrm{Br} J$ Cancer 2004, 90:93-99.
25. Chiang N, Serhan CN, Dahlén SE, Drazen JM, Hay DWP, Rovati GE, Shimizu T, Yokomizo T, Brink C: The Lipoxin Receptor ALX: Potent Ligand-Specific and Stereoselective Action in Vivo. Pharmacol Rev 2006, 58:463-487.

26. Petrik MB, McEntee MF, Chiu CH, Whelan J: Antagonism of Arachidonic Acid Is Linked to the Antitumorigenic Effect of Dietary Eicosapentaenoic Acid in Apc ${ }^{\text {Min/1 }}$ Mice. J Nutr 2000, 130:1153-1158.

27. Imai N, Kawabe M, Tamano S, Doi Y, Nakashima H, Suguro M, Numano T, Hara T, Hagiwara A, Furukawa F, Kaneda Y, Tateishi N, Fujii W, Kawashima H, Shibata H, Sakakibara Y: Arachidonate-enriched triglyceride oil does not promote tumor development in a rat medium-term multi-organ carcinogenesis model. Food Chem Toxicol 2012, 50:2780-2791.

28. Lin J, Zhang SM, Cook NR, Lee IM, Buring JE: Dietary fat and fatty acids and risk of colorectal cancer in women. Am J Epidemiol 2004, 160:1011-1022.

29. Saadatian-Elahi M, Toniolo P, Ferrari P, Goudable J, Akhmedkhanov A, Zeleniuch-Jacquotte A, Riboli E: Serum fatty acids and risk of breast cancer in a nested case-control study of the New York University Women's Health Study. Canc Epidemiol Biomarkers Prev 2002, 11:1353-1360

30. Murff HJ, Shu XO, Li H, Dai Q, Kallianpur A, Yang G, Cai H, Wen W, Gao YT, Zheng W: A prospective study of dietary polyunsaturated fatty acids and colorectal cancer risk in Chinese women. Canc Epidemiol Biomarkers Prev 2009, 18:2283-2291.

31. Nkondjock A, Shatenstein B, Maisonneuve P, Ghadirian P: Assessment of risk associated with specific fatty acids and colorectal cancer among French-Canadians in Montreal: a case-control study. Int J Epidemiol 2003, 32:200-209.

32. Caleffi M, Ashraf J, Rowe PH, Thomas BS, Fentiman IS: A comparison of the fatty acid profiles of subcutaneous fat from women with breast cancer, benign breast disease and normal controls. Anticancer Res 1987, 7:1305-1307.

33. von Elm E, Altman DG, Egger M, Pocock SJ, Gøtzsche PC, Vandenbroucke JP, STROBE Initiative: Strengthening the Reporting of Observational Studies in Epidemiology (STROBE) statement: guidelines for reporting observational studies. BMJ 2007, 335:806-808.

34. Hall MN, Campos H, Li H, Sesso HD, Stampfer MJ, Willett WC, Ma J: Blood levels of long-chain polyunsaturated fatty acids, aspirin, and the risk of colorectal cancer. Canc Epidemiol Biomarkers Prev 2007, 16:314-321.

35. Kojima M, Wakai K, Tokudome S, Suzuki K, Tamakoshi K, Watanabe Y, Kawado M, Hashimoto S, Hayakawa N, Ozasa K, Toyoshima H, Suzuki S, Ito Y, Tamakoshi A, JACC Study Group: Serum levels of polyunsaturated fatty acids and risk of colorectal cancer: a prospective study. Am J Epidemiol 2005, 161:462-471.

36. Theodoratou E, McNeill G, Cetnarskyj R, Farrington SM, Tenesa A, Barnetson R, Porteous M, Dunlop M, Campbell H: Dietary fatty acids and colorectal cancer: a case-control study. Am J Epidemiol 2007, 166:181-195.

37. Slattery ML, Potter JD, Duncan DM, Berry TD: Dietary fats and colon cancer: assessment of risk associated with specific fatty acids. Int J Cancer 1997, 73:670-677.

38. Kuriki K, Wakai K, Hirose K, Matsuo K, Ito H, Suzuki T, Saito T, Kanemitsu Y, Hirai T, Kato T, Tatematsu M, Tajima K: Risk of colorectal cancer is linked to erythrocyte compositions of fatty acids as biomarkers for dietary intakes of fish, fat, and fatty acids. Canc Epidemiol Biomarkers Prev 2006, 15:1791-1798.

39. Busstra MC, Siezen CL, Grubben MJ, van Kranen HJ, Nagengast FM, van't Veer P: Tissue levels of fish fatty acids and risk of colorectal adenomas: a case-control study (Netherlands). Canc Causes Contr 2003, 14:269-276.

40. Ghadimi R, Kuriki K, Tsuge S, Takeda E, Imaeda N, Suzuki S, Sawai A, Takekuma K, Hosono A, Tokudome Y, Goto C, Esfandiary I, Nomura H, Tokudome S: Serum concentrations of fatty acids and colorectal adenoma risk: a case-control study in Japan. Asian PaC J Canc Prev 2008, 9:111-118.

41. Baró $L$, Hermoso JC, Núñez MC, Jiménez-Rios JA, Gil A: Abnormalities in plasma and red blood cell fatty acid profiles of patients with colorectal cancer. Br J Cancer 1998, 77:1978-1983.

42. Neoptolemos JP, Thomas BS: Erythrocyte membrane stearic acid: oleic acid ratios in colorectal cancer using tube capillary column gas liquid chromatography. Ann Clin Biochem 1990, 27:38-43.

43. Neoptolemos JP, Clayton H, Heagerty AM, Nicholson MJ, Johnson B, Mason J, Manson K, James RF, Bell PR: Dietary fat in relation to fatty acid composition of red cells and adipose tissue in colorectal cancer. Br J Cancer 1988, 58:575-579. 
44. Almendingen K, Høstmark AT, Fausa O, Mosdøl A, Aabakken L, Vatn MH: Familial adenomatous polyposis patients have high levels of arachidonic acid and docosahexaenoic acid and low levels of linoleic acid and alphalinolenic acid in serum phospholipids. Int J Cancer 2006, 120:632-637.

45. Fernández-Bañares F, Esteve M, Navarro E, Cabré E, Boix J, Abad-Lacruz A, Klaassen J, Planas R, Humbert P, Pastor C, Gassull MA: Changes of the mucosal n3 and n6 fatty acid status occur early in the colorectal adenoma-carcinoma sequence. Gut 1996, 38:254-259.

46. Hietanen E, Bartsch H, Béréziat JC, Camus AM, McClinton S, Eremin O, Davidson L, Boyle P: Diet and oxidative stress in breast, colon and prostate cancer patients: a case-control study. Eur J Clin Nutr 1994, 48:575-586.

47. Berry EM, Zimmerman J, Peser M, Ligumsky M: Dietary fat, adipose tissue composition, and the development of carcinoma of the colon. J Natl Canc Inst 1986, 77:93-97.

48. Hakim IA, Harris RB, Ritenbaugh C: Fat intake and risk of squamous cell carcinoma of the skin. Nutr Canc 2000, 36:155-162.

49. Harris RB, Foote JA, Hakim IA, Bronson DL, Alberts DS: Fatty acid composition of red blood cell membranes and risk of squamous cell carcinoma of the skin. Canc Epidemiol Biomarkers Prev 2005, 14:906-912.

50. Mackie BS, Mackie LE, Curtin LD, Bourne DJ: Melanoma and dietary lipids. Nutr Canc 1987, 9:219-226.

51. Holmes MD, Hunter DJ, Colditz GA, Stampfer MJ, Hankinson SE, Speizer FE, Rosner B, Willett WC: Association of dietary intake of fat and fatty acids with risk of breast cancer. JAMA 1999, 281:914-920.

52. Voorrips LE, Brants HA, Kardinaal AF, Hiddink GJ, van den Brandt PA, Goldbohm RA: Intake of conjugated linoleic acid, fat, and other fatty acids in relation to postmenopausal breast cancer: the Netherlands Cohort Study on Diet and Cancer. Am J Clin Nutr 2002, 76:873-882.

53. Pala $V$, Krogh $V$, Muti $P$, Chajès $V$, Riboli $E$, Micheli $A$, Saadatian M, Sieri $S$, Berrino F: Erythrocyte membrane fatty acids and subsequent breast cancer: a prospective Italian study. J Natl Canc Inst 2001, 93:1088-1095.

54. Chajès V, Hultén $K$, Van Kappel AL, Winkvist A, Kaaks R, Hallmans G, Lenner $P$, Riboli E: Fatty-acid composition in serum phospholipids and risk of breast cancer: an incident case-control study in Sweden. Int J Cancer 1999, 83:585-590.

55. Nkondjock A, Shatenstein B, Ghadirian P: A case-control study of breast cancer and dietary intake of individual fatty acids and antioxidants in Montreal, Canada. Breast 2003, 12:131-138.

56. Vatten LJ, Bjerve KS, Andersen A, Jellum E: Polyunsaturated fatty acids in serum phospholipids and risk of breast cancer: a case-control study from the Janus serum bank in Norway. Eur J Cancer 1993, 29A:532-538.

57. London SJ, Sacks FM, Stampfer MJ, Henderson IC, Maclure M, Tomita A, Wood WC, Remine S, Robert NJ, Dmochowski JR, Willett WC: Fatty acid composition of the subcutaneous adipose tissue and risk of proliferative benign breast disease and breast cancer. J Natl Canc Inst 1993, 85:785-793.

58. Zhu ZR, Ågren J, Männistö S, Pietinen P, Eskelinen M, Syrjänen K, Uusitupa M: Fatty acid composition of breast adipose tissue in breast cancer patients and in patients with benign breast disease. Nutr Canc 1995, 24:151-160.

59. Aro A, Männistö S, Salminen I, Ovaskainen ML, Kataja V, Uusitupa M: Nutr Inverse association between dietary and serum conjugated linoleic acid and risk of breast cancer in postmenopausal women. Cancer 2000, 38:151-157.

60. Zaridze DG, Chevchenko VE, Levtshuk AA, Lifanova YE, Maximovitch DM: Fatty acid composition of phospholipids in erythrocyte membranes and risk of breast cancer. Int J Cancer 1990, 45:807-810.

61. Bagga D, Anders KH, Wang HJ, Glaspy JA: Long-chain n-3-to-n-6 polyunsaturated fatty acid ratios in breast adipose tissue from women with and without breast cancer. Nutr Canc 2002, 42:180-185.

62. Maillard $V$, Bougnoux $P$, Ferrari $P$, Jourdan $M L$, Pinault $M$, Lavillonnière $F$, Body $\mathrm{G}$, Le Floch $\mathrm{O}$, Chajès $\mathrm{V}$ : N-3 and $\mathrm{n}-6$ fatty acids in breast adipose tissue and relative risk of breast cancer in a case-control study in Tours, France. Int J Cancer 2002, 98:78-83.

63. Petrek JA, Hudgins LC, Levine B, Ho M, Hirsch J: Breast cancer risk and fatty acids in the breast and abdominal adipose tissues. J Natl Canc Inst 1994, 86:53-56.

64. Williams CM, Maunder K: Fatty acid compositions of inositol and choline phospholipids of breast tumours and normal breast tissue. Eur J Clin Nutr 1993, 47:260-267.
65. Punnonen K, Hietanen E, Auvinen O, Punnonen R: Phospholipids and fatty acids in breast cancer tissue. J Cancer Res Clin Oncol 1989, 115:575-578.

66. Eid A, Berry EM: The relationship between dietary fat, adipose tissue composition, and neoplasms of the breast. Nutr Canc 1988, 11:173-177.

67. Leitzmann MF, Stampfer MJ, Michaud DS, Augustsson K, Colditz GC, Willett WC, Giovannucci EL: Dietary intake of $n-3$ and $n-6$ fatty acids and the risk of prostate cancer. Am J Clin Nutr 2004, 80:204-216.

68. Männistö S, Pietinen P, Virtanen MJ, Salminen I, Albanes D, Giovannucci E, Virtamo J: Fatty acids and risk of prostate cancer in a nested case-control study in male smokers. Canc Epidemiol Biomarkers Prev 2003, 12:1422-1428.

69. Schuurman AG, van den Brandt PA, Dorant E, Brants HA, Goldbohm RA: Association of energy and fat intake with prostate carcinoma risk: results from The Netherlands Cohort Study. Cancer 1999, 86:1019-1027.

70. Crowe FL, Allen NE, Appleby PN, Overvad K, Aardestrup IV, Johnsen NF, Tjønneland A, Linseisen J, Kaaks R, Boeing H, Kröger J, Trichopoulou A, Zavitsanou A, Trichopoulos D, Sacerdote C, Palli D, Tumino R, Agnoli C, Kiemeney LA, Bueno-de-Mesquita HB, Chirlaque MD, Ardanaz E, Larrañaga N, Quirós JR, Sánchez MJ, González CA, Stattin P, Hallmans G, Bingham S, Khaw KT, Rinaldi S, Slimani N, Jenab M, Riboli E, Key TJ: Fatty acid composition of plasma phospholipids and risk of prostate cancer in a case-control analysis nested within the European Prospective Investigation into Cancer and Nutrition. Am J Clin Nutr 2008, 88:1353-1363.

71. Chavarro JE, Stampfer MJ, Li H, Campos H, Kurth T, Ma J: A prospective study of polyunsatutated fatty acid levels in blood and prostate cancer risk. Canc Epidemiol Biomarkers Prev 2007, 16:1364-1370.

72. Harvei S, Bjerve KS, Tretli S, Jellum E, Robsahm TE, Vatten L: Prediagnostic level of fatty acids in serum phospholipids: omega- 3 and omega- 6 fatty acids and the risk of prostate cancer. Int J Cancer 1997, 71:545-551

73. Gann PH, Hennekens CH, Sacks FM, Grodstein F, Giovannucci EL, Stampfer MJ: Prospective study of plasma fatty acids and risk of prostate cancer. J Natl Canc Inst 1994, 86:281-286.

74. Hodge AM, English DR, McCredie MR, Severi G, Boyle P, Hopper JL, Giles GG: Foods, nutrients and prostate cancer. Canc Causes Contr 2004, 15:11-20.

75. Ukoli FA, Fowke JH, Akumabor P, Oguike T, Taher KA, Murff HJ, Amaefuna ER, Kittles R, Ahaghotu C, Osime U, Beech DJ: The association of plasma fatty acids with prostate cancer risk in African Americans and Africans. $J$ Health Care Poor Underserved 2010, 21(Suppl 1):127-147.

76. Ukoli FA, Akumabor PN, Oguike TC, Dent LL, Beech D, Osime U: The association of plasma fatty acids with prostate cancer risk in Nigerians. Ethn Dis 2009, 19:454-461.

77. Newcomer LM, King IB, Wicklund KG, Stanford JL: The association of fatty acids with prostate cancer risk. Prostate 2001, 47:262-268.

78. Yang YJ, Lee SH, Hong SJ, Chung BC: Comparison of fatty acid profiles in the serum of patients with prostate cancer and benign prostatic hyperplasia. Clin Biochem 1999, 32:405-409.

79. Faas FH, Dang AQ, White J, Schaefer RF, Johnson DE: Decreased prostatic arachidonic acid in human prostatic carcinoma. BJU Int 2003, 92:551-554.

80. Chaudry A, McClinton S, Moffat LE, Wahle KW: Essential fatty acid distribution in the plasma and tissue phospholipids of patients with benign and malignant prostatic disease. Br J Cancer 1991, 64:1157-1160.

81. Mamalakis G, Kafatos A, Kalogeropoulos N, Andrikopoulos N, Daskalopulos G, Kranidis A: Prostate cancer vs hyperplasia: relationships with prostatic and adipose tissue fatty acid composition. Prostag Leukot Essent Fatty Acids 2002, 66:467-477

82. Kobayashi M, Sasaki S, Kawabata T, Hasegawa K, Tsugane S, JPHC: Validity of a self-administered food frequency questionnaire used in the 5-year follow-up survey of the JPHC Study Cohort I to assess fatty acid intake: comparison with dietary records and serum phospholipid level. J Epidemiol 2003, 13(Suppl 1):S64-S81.

83. Elmadfa I, Kornsteiner M: Fats and Fatty Acid Requirements for Adults. Ann Nutr Metab 2009, 55:56-75.

84. Kawabata T, Hirota S, Hirayama T, Adachi N, Hagiwara C, Iwama N, Kamachi K, Araki E, Kawashima H, Kiso Y: Age-related changes of dietary intake and blood eicosapentaenoic acid, docosahexaenoic acid, and arachidonic acid levels in Japanese men and women. Prostag Leukot Essent Fatty Acids 2011, 84:131-137. 
85. Arab L: Biomarkers of Fat and Fatty Acid Intake. J Nutr 2003, 133(Suppl 3):925S-932S.

86. Garland M, Sacks FM, Colditz GA, Rimm EB, Sampson LA, Willett WC, Hunter DJ: The relation between dietary intake and adipose tissue composition of selected fatty acids in US women. Am J Clin Nutr 1998, 67:25-30.

87. Kakutani S, Ishikura Y, Tateishi N, Horikawa C, Tokuda H, Kontani M, Kawashima H, Sakakibara Y, Kiso Y, Shibata H, Morita I: Supplementation of arachidonic acid-enriched oil increases arachidonic acid contents in plasma phospholipids, but does not increase their metabolites and clinical parameters in Japanese healthy elderly individuals: a randomized controlled study. Lipids Health Dis 2011, 10:241.

88. Chen Y, Hao H, He S, Cai L, Li Y, Hu S, Ye D, Hoidal J, Wu P, Chen X: Lipoxin $\mathrm{A}_{4}$ and Its Analogue Suppress the Tumor Growth of Transplanted H22 in Mice: The Role of Antiangiogenesis. Mol Cancer Ther 2011, 9:2164-2174.

doi:10.1186/1471-2407-12-606

Cite this article as: Sakai et al:: Arachidonic acid and cancer risk: a systematic review of observational studies. BMC Cancer 2012 12:606.

\section{Submit your next manuscript to BioMed Central and take full advantage of:}

- Convenient online submission

- Thorough peer review

- No space constraints or color figure charges

- Immediate publication on acceptance

- Inclusion in PubMed, CAS, Scopus and Google Scholar

- Research which is freely available for redistribution 